Izvorni znanstveni rad

UDK 796.525.(497.57)"1984/2010”(091)

DOI https://doi.org/10.54130/zl.8.1.3

\title{
Igor Eterović
}

Medicinski fakultet Sveučilišta u Rijeci

Katedra za društvene i humanističke znanosti u medicini

Braće Branchetta 20, HR-51000 Rijeka

igor.eterovic@uniri.hr

\section{Ivana Eterović}

Filozofski fakultet Sveučilišta u Zagrebu

Odsjek za kroatistiku

Ivana Lučića 3, HR-10000 Zagreb

isankovi@ffzg.hr

\section{PRILOG POZNAVANJU POVIJESTI LIBURNIJSKOGA PLANINARSTVA: DJELOVANJE PLANINARSKOGA DRUŠTVA „ORLJAK“ OPATIJA (1984.-2010.)}

U povijesti hrvatskoga planinarstva djelovanje Planinarskoga društva „Orljak“ iz Opatije (dalje: Društvo) slabo je poznato, no njegov četvrtstoljetni rad i zapažene aktivnosti na području Liburnije ukazuju na opravdanost dokumentiranja te važne epizode lokalne, regionalne, pa i nacionalne planinarske povjesnice. U ovome se članku stoga istražuje rad i djelovanje Društva od njegovih pretpočetaka u obliku Planinarskoga aktiva „Orljak“, koji djeluje u okviru Planinarskoga društva „Opatija“ (od 1980.), preko osnivanja samostalnoga Društva (1984.) te razdoblja rasta i intenzivna rada 1980-ih, postupna zamiranja 1990-ih i naposljetku nekoliko zabilježenih bljeskova značajnijih aktivnosti u početnome desetljeću 21. stoljeća. Rad se temelji na temeljitoj analizi dosad neobjavljenih arhivskih izvora iz nekoliko različitih fondova, a ti su podaci dopunjeni intervjuima s pojedincima koji su u određenome razdoblju bili aktivni članovi Društva te sekundarnom literaturom. Riječ je o dosad slabo poznatim podacima, čak i unutar planinarskih krugova,

1 U pisanju ovoga rada pomogli su nam mnogi ustupanjem građe iz privatnih i javnih arhiva, stoga im na ovome mjestu svima srdačno zahvaljujemo. Bivši članovi Planinarskoga društva „Orljak“ Cvjetana Miletić, Zoran Rubeša i Radovan Trinajstić posudili su nam svoje fotografije, dokumente i/ili planinarske dnevnike. Glavni tajnik Hrvatskoga planinarskog saveza Alan Čaplar omogućio nam je uvid u građu koju čuva krovni nacionalni sportski savez, a djelatnik opatijske ispostave Upravnoga odjela za opću upravu i upravljanje imovinom Primorsko-goranske županije Gordan Ožaković u dokumente koji se ondje čuvaju. Cvjetana Miletić posudila nam je pak sva godišta Opatijske komune, a Jasna Doričić-Sanković Lista Opatija. 
stoga se ovim istraživanjem nastoji ne samo spasiti od zaborava djelovanje jedne planinarske udruge nego $i$ adekvatno valorizirati njezin rad kao trajno naslijeđe lokalne, regionalne i nacionalne (planinarske) povijesti.

Ključne riječi: planinarstvo, zaštita prirode, Liburnija, Opatija, Planinarsko društvo „Orljak“

\section{Uvod}

Početkom organiziranoga planinarstva u Opatiji smatra se osnivanje planinarske sekcije Austrijskoga turističkog kluba u Voloskom 4. lipnja 1885. godine (Eterović i Ružić 2021: 13). Nakon što je 1893. godine rad te sekcije ugašen, u Opatiji se pojavljuju sporadični pokušaji osnivanja novih planinarskih društava krajem 19. i početkom 20. stoljeća, no bez značajnijih rezultata, dok će uspješno osnivanje planinarskoga društva u Opatiji uslijediti tek sredinom 20. stoljeća (Eterović i Ružić 2021: 13-14). Naime krajem 1950. godine održana je osnivačka skupština Planinarskoga društva „Opatija“, koje će biti službeno upisano u registar udruga početkom 1951. godine (Eterović i Ružić 2021: 15). Tijekom sedamdeset godina njegova postojanja djelovat će u njegovu sastavu više različitih aktiva, koji se osnivaju pri školama ili poduzećima (Eterović i Ružić 2021: 61). Premda se oni većinom brzo i gase, jedan će aktiv postati jezgrom novoga opatijskoga planinarskog društva. Riječ je o planinarskome aktivu, a kasnije planinarskome društvu - „Orljak“.

Nijedan od osnovanih planinarskih aktiva neće nadživjeti matično društvo, što je sudbina koja je naposljetku zadesila i Planinarsko društvo „Orljak“. Bez obzira na sve svoje uspone i padove, Planinarsko društvo „Opatija“ ostat će na kraju ne samo jedinim opatijskim nego i jedinim istarskim planinarskim društvom koje bez prekida djeluje sve do danas. Među zabilježenim planinarskim društvima, aktivima i/ili družinama koji su djelovali na liburnijskome, mahom opatijskome, području monografski je dosad prikazano samo sedamdesetogodišnje djelovanje Planinarskoga društva „Opatija“ (Eterović i Ružić 2021). Ovim radom želimo pridonijeti popunjavanju te praznine, stoga u njemu prikazujemo četvrtstoljetno djelovanje Planinarskoga društva „Orljak“ iz Opatije s ciljem pružanja priloga boljemu poznavanju povijesti opatijskoga, istarskoga i hrvatskoga planinarstva.

U pisanju smo se ovoga rada oslanjali ponajprije na arhivsku građu vezanu za Planinarsko društvo „Orljak“ koja se čuva u javnim i privatnim arhivima. Među javnim arhivima valja spomenuti na prvome mjestu dokumente iz opatijske ispostave Upravnoga odjela za opću upravu i upravljanje imovinom Primorsko-goranske županije, a potom dokumente iz krovnoga nacionalnoga sportskog saveza za područje planinarstva - Hrvatskoga planinarskog saveza. Djelovanje Društva rekonstruirano je dalje pomoću periodike, i to članaka iz glasila nekadašnje Općine Opatija Opatijska komuna i službenoga glasila Hrvatskoga planinarskog saveza Naše planine / Hrvatski planinar. Djelovanje Društva dodatno 
su rasvijetlili podaci iz privatnih arhiva njegova dugogodišnjega predsjednika Zorana Rubeše i višegodišnjih aktivnih članova Radovana Trinajstića te Tomislava i Cvjetane Miletić, a s kojima su obavljeni i intervjui.

Zahvaljujući svim navedenim izvorima može se uočiti nekoliko faza u djelovanju Planinarskoga društva „Orljak“: od njegovih pretpočetaka u obliku Planinarskoga aktiva „Orljak“, koji djeluje u okviru Planinarskoga društva „Opatija“ (od 1980.), preko osnivanja samostalnoga Društva (1984.) te razdoblja rasta i intenzivna rada 1980-ih, postupna zamiranja 1990-ih i naposljetku nekoliko zabilježenih bljeskova značajnijih aktivnosti u početnome desetljeću 21. stoljeća. Upravo će prema tim fazama biti strukturiran prikaz djelovanja Planinarskoga društva „Orljak“ u nastavku rada.

\section{Pretpočeci: djelovanje aktiva u okviru Planinarskoga društva „Opatija“}

Godine 1980. grupa planinara okupljena oko vatrogasne postrojbe u Opatiji, a predvođena Marijanom Rubešom, osniva Planinarski aktiv „Orljak“ u okviru Planinarskoga društva „Opatija“, čija je aktivnost na samome početku rada bila vrlo snažna:

[...] na Dan Republike 1980. g. na Veloj Učki osnovan je aktiv pri „Dobrovoljnom vatrogasnom društvu“ iz Opatije sa popriličnim brojem omladinaca. Ovaj je aktiv pokazao dosta ambicije na početku svojega rada, organizirao je par izleta na području Učke, Lisine i Gorskog kotara, poseban pohod uz postavljanje bivaka na Orljaku a sprema se na daljne, društvene akcije. Od početnih desetak članova aktiva, ubrzo je taj broj takodjer dostigao oko 30 članova a na čelu pododbora nalazi se Rubeša Marijan. (HPS Balen 1981: 12)

O osnivanju aktiva postoji opširno izvješće u Opatijskoj komuni, gdje se navodi da je ,,[u] prostorijama Doma 1. istarske partizanske čete na Veloj Učki održan osnivački sastanak planinarskog aktiva 'Orljak' koji će djelovati u sastavu planinarskog društva 'Opatija'." (Trinajstić 1981), da je sastanak otvorio Marijan Rubeša, a da je o dužnostima svakog člana planinara govorio Boris Križan, nakon čega je izabrano rukovodstvo aktiva: „Za predsjednika je izabran jednoglasno Marijan Rubeša, Anton Šorić za zamjenika, Franko Ivančić i Damir Rakovac za tajnika, Zoran Rubeša za blagajnika te kao članovi Boris Kozulić i Ivica Rubeša.“ (Trinajstić 1981) U nastavku toga izvješća ukratko se prikazuju postavljeni zadaci, s kojima je u uskoj vezi i odabir samoga imena aktiva:

Planinarski aktiv „Orljak“ u narednom će razdoblju imati zadatak da tijesno razvija suradnju sa SUBNOR²-om Opatija, DVD ${ }^{3}$ Opatija te društve-

2 Savez udruga antifašističkih boraca Narodnooslobodilačkog rata.

3 Dobrovoljna vatrogasna postrojba. 
no-političkim organizacijama općine Opatija ${ }^{4}$ na očuvanju tekovina NOR-a ${ }^{5}$ i održavanju spomen obilježja palih boraca. Planinarski aktiv „Orljak“ dobio je ime po brdu, na čijoj je koti $706^{6}$, Prvog svibnja 1940. podignuta crvena partijska zastava. Organizatori podizanja zastave bili su komunisti Rukavca i Kućela na čelu s Bertom Jurdana i Jakovom Brajanom. Zastavu su podigli Aleksio Poščić iz Mihotića i Stanko Jurdana iz Kućela, koji su pored brojne nadmoći neprijatelja izvršili smjelo svoj zadatak. Okolno stanovništvo s oduševljenjem je pratilo izvršenje zadatka i pozdravljalo ovu akciju. (Trinajstić 1981)

U tome navodu, donesenu u cijelosti, odražava se početna motivacija Planinarskoga društva „Orljak“, pri čemu će upravo sjećanje na pojedine povijesne događaje (uglavnom vezane za NOR) i očuvanje određenih običaja (kasnije paljenje krijesa na Orljaku) biti svojevrstan lajt-motiv Društva i njegova djelovanja na širem području Učke i Ćićarije s brdom Orljak kao simboličkim središtem njegova identiteta. U izvorima se tako bilježi primjerice da su između ostaloga „planinari Planinarskog društva Opatija, aktiv 'Orljak'“ 1981. godine aktivno sudjelovali u pripremama i realizaciji prvomajske svečanosti na Orljaku i oko njega, prvenstveno na prostoru zvanom Zadušcina iznad veprinačkih zaselaka Vedež i Zagrad“ (Miletić 1981). O istoj se aktivnosti izvještava temeljitije na drugom mjestu:

Grupa planinara Planinarskog društva Opatija - aktiva „Orljak“ u suradnji s izviđačima Rukavca, postavili su 30. travnja na Orljaku crvenu zastavu.

$\mathrm{Na}$ Orljaku su logorovali četiri dana i sudjelovali na proslavi „Zastava na Orljaku“.

Uoči 1. maja upalili su krijes i upriličili vatromet.

Planinari aktiva „Orljak“ redovno surađuju s Općinskim odborom SUBNOR-a prilikom organiziranja proslava i posjeta značajnim mjestima iz NOB-a $a^{7}$ na području općine Opatija. (Stanta 1981)

Organizacija te svečanosti nije ni sljedeće, 1982. godine protekla bez sudjelovanja Planinarskoga aktiva „Orljak“:

U proslavi na Orljaku uoči 1. maja sudjelovalo je i 30 planinara Planinarskog društva „Opatija“. Uoči praznika 10 članova planinarskog aktiva „Orljak“ i 8 izviđača IV čete „S. Jurdana“ iz Rukavca organizirali su zajedničko logorovanje. Naveče je podignuta crvena zastava, upaljena logorska vatra i priređen vatromet. Na spomenik palim borcima u Veprincu i na spomen-ploči na Orljaku položeno je cvijeće. Nakon svečanosti na vrhu Orljaka i parti-

4 Nekadašnja Općina Opatija zauzimala je područje današnje Liburnije i tzv. Opatijskog krasa, tj. objedinjavala je teritorij nekoliko današnjih jedinica lokalne samouprave (općine Mošćenička Draga, Lovran i Matulji te Grad Opatiju).

5 Narodnooslobodilački rat.

6 Ovdje iznesena kota nije točna - izmjere na karti govore o 711 metara nadmorske visine samoga brda.

7 Narodnooslobodilačka borba. 
zanskog ručka na Zadušćini, nekoliko je planinara nastavilo pješački pohod preko Veprinca, Poljana i Pećnika do Lovrana. (Stanta 1982)

Ovdje treba posebno istaknuti nešto što će kasnije obilježiti Društvo, a to je bliskost s izviđačima i njihovim vidom boravka u prirodi. To je najbolje vidljivo iz dugih pješačkih pohoda koji nisu obremenjeni dolascima na određeni vrh te iz posvećenosti logorovanju kao važnu obliku boravka u prirodi, bez obzira na to odvija li se ono u neposrednome planinskom zaleđu. Sve se to na neki način odmicalo od klasična, konzervativna pogleda na planinarenje, u čemu se može zamijetiti klica distanciranja Aktiva od matičnoga društva - Planinarskoga društva „Opatija“".

U izvještaju sljedeće godine donosi se ponovno podatak o sudjelovanju Aktiva u organizaciji svečanosti na Orljaku 1983., ali je veoma važan i znakovit uvodni dio toga izvještaja, koji govori da se Aktiv posebno posvetio radu s mladima, gdje treba tražiti još jednu liniju razilaženja u viziji razvoja i pogledu na rad s mladima kao imperativ planinarstva:

Planinarski aktiv „Orljak“ pri Vatrogasnoj jedinici Opatija veoma je aktivan. Već tri godine, koliko djeluje, uspješno je uključen u organizaciju brojnih društveno-političkih manifestacija i orijentaciona natjecanja. Posebna pažnja posvećuje se radu s omladinom. Planinarska organizacija u Opatiji ima velik broj mladih ,na papiru“, ali je vrlo malen broj aktivan, pa je rad s mladima tim više značajan. (Stanta 1983)

U tim recima može se uočiti još jedan stup djelatnosti čijem je razvijanju stremio Aktiv, a koji nije pripadao klasičnoj planinarskoj djelatnosti na koju su planinarska društva navikla - orijentacijska natjecanja (Trinajstić 2021). U nastavku izvještaja ponovno se ističe kako su planinari Aktiva sudjelovali u organizaciji prvomajske svečanosti te su ,već 30. travnja podigli [...] na Orljaku logor, uveče zapalili krijes i izvjesili veliku crvenu zastavu, u znak sjećanja [...]“ na spomenute događaje iz 1940. (Stanta 1983).

Uza spomenute okosnice u radu Aktiva utvrđene na temelju dosad citiranih izvještaja - očuvanje običaja, naglasak na radu s mladima, bliskost izviđačkoj filozofiji (logorovanje, druženje u prirodi kao imperativ), orijentacijska trčanja možda je još bolji primjer njegova razilaženja od matičnoga društva pojava tzv. „transverzalaca“. Naime grupa članova Aktiva posvetila se u jednome trenutku sustavnu posjećivanju brojnih planinarskih obilaznica - transverzala, u smislenu cjelinu zaokruženih planinarskih putova koje uvijek nužno prati dnevnik, a ponekad i vodič u obliku tanje knjižice. Dio članova sigurno je na to gledao kao na trenutnu modu i planinarsku novotariju koja je bila planinarska devijacija (,,̌igomanija" - trka za žigovima, umjesto uživanja u planini i prirodi, koja prijeđe i svaku granicu planinarske etike; usp. Slaviček 1984) u odnosu na klasične planinarske vrednote (užitak u samoj stazi, ljepota određenog smjera u stijeni, izazov i zahtjevnost dolaska na vrh itd.). Zbog svega toga pošlo se u osnivanje samostalnog planinarskog društva (Trinajstić 2021). O aktivnosti, ustrajnosti i ozbiljnosti „,transverzalaca“ najbolje govori niz sačuvanih dopisa Marijana i Ivice Rubeše 
uime Aktiva prema Planinarskom savezu Hrvatske, odnosno pojedinim društvima izdavačima s upitima o novim transverzalama, o mogućnosti njihove nabave te o savjetima kako do njih doći (HPS M. Rubeša 1983a, 1983b, 1983c; HPS I. Rubeša 1983a, 1983b). Međutim o toj aktivnosti još živopisnije govori broj što započetih što dovršenih transverzala jednoga od najaktivnijih ,transverzalaca“ $u$ to vrijeme u Društvu - Radovana Trinajstića.

Snaga Aktiva vidljiva je i na temelju jednoga od spomenutih dopisa Planinarskom savezu Hrvatske, gdje je osim transverzala bilo traženo i 10 značaka Saveza, raspitivalo se o literaturi radi obuke članstva u orijentaciji i topografiji te se molila potvrda primitka pretplate na časopis Naše planine (HPS Rubeša 1983a), što govori u prilog tomu da je Aktiv već pomalo prerastao svoje okvire djelujući gotovo samostalno. Da je bio ozbiljno organiziran, svjedoči i činjenica da je imao vlastiti znak, odnosno žig: konture grebena planine Učke sa stilizacijom stabala/šume podno grebena; na desnoj gornjoj strani markacija, a ispod more s dvije stilizirane jedrilice i dva stilizirana galeba; iznad grebena piše Planinarski aktiv „Orljak“, a ispod Opatija.

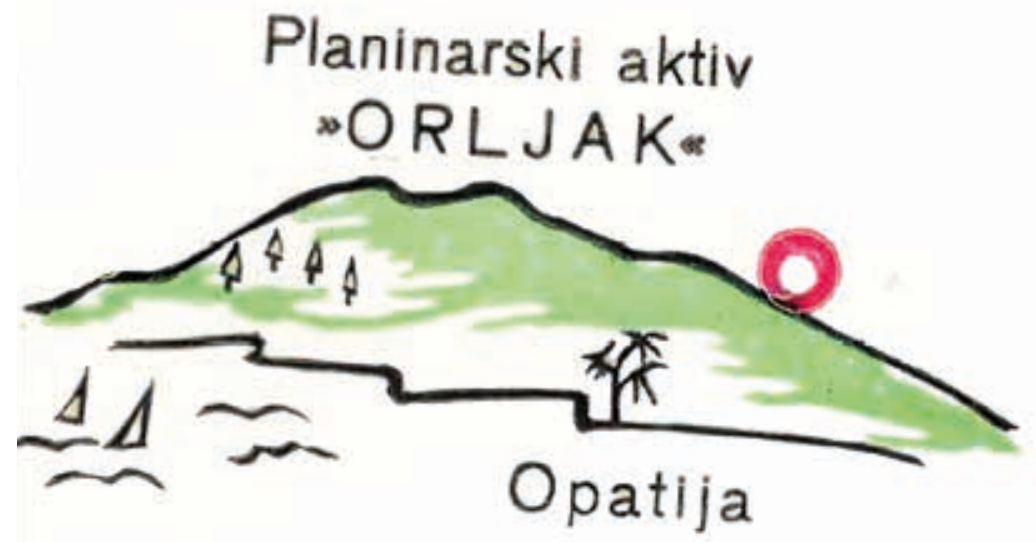

Slika 1. Znak Planinarskoga aktiva „Orljak“. Arhiva Radovana Trinajstića.

Figure 1. Logo of the Mountaineering Section „Orljak“. Radovan Trinajstić's archive.

Uz tradicionalna zimovanja, koja su u organizaciji Planinarskoga društva „Opatija“ bila organizirana u Planinarskom domu „Poklon“ (Stanta 1984a), ${ }^{8}$ Aktiv samostalno 1984. godine prvi put organizira paralelno sedmodnevno zimovanje:

Članovi Planinarskog aktiva „Orljak“ iz Opatije boravili su na sedmodnevnom zimovanju na padinama Planika, u predjelu zvanom Brdo. Svoje zimovanje planinari su uspješno ostvarili uz pomoć i razumijevanje članova opatijskog lovačkog društva „Lane“ koji su im ustupili svoju lovačku kućicu.

8 Više o zimovanjima u organizaciji Planinarskoga društva „Opatija“v. u Eterović i Ružić 2021: 177-185. 
Na zimovanju je bilo 10 planinara pod vodstvom Marijana i Ivice Rubeše.

(Trinajstić 1984a)

U nastavku se napominje da su planinari ,vrijeme iskoristili za kratke šetnje i izlete u okolinu te za skijanje na snijegom pokrivenim padinama", večernje sate provodeći ,zabavljajući se društvenim igrama i gledajući TV program“, a da je cijelo zimovanje ostvareno ,uz punu angažiranost Profesionalne vatrogasne jedinice Opatija i komandira Lucijana Slavića“ (Trinajstić 1984a). Osobna podrška zapovjednika i cjelokupna logistička podrška PVJ-a Opatija bit će ključna u nastanku samostalnoga planinarskog društva i nastavku njegova razvoja, kako će se uskoro pokazati.

O aktivnosti Aktiva svjedoči i masovnost, koju je brzo postigao djelujući, kako je spomenuto, u nekim drugim, možda i novijim smjerovima razvijanja planinarstva. To razilaženje u viziji daljnjega razvoja prirodno je dovelo do ideje da se aktiv treba osamostaliti i osnovati kao zasebno planinarsko društvo, što će se i dogoditi 1984. godine.

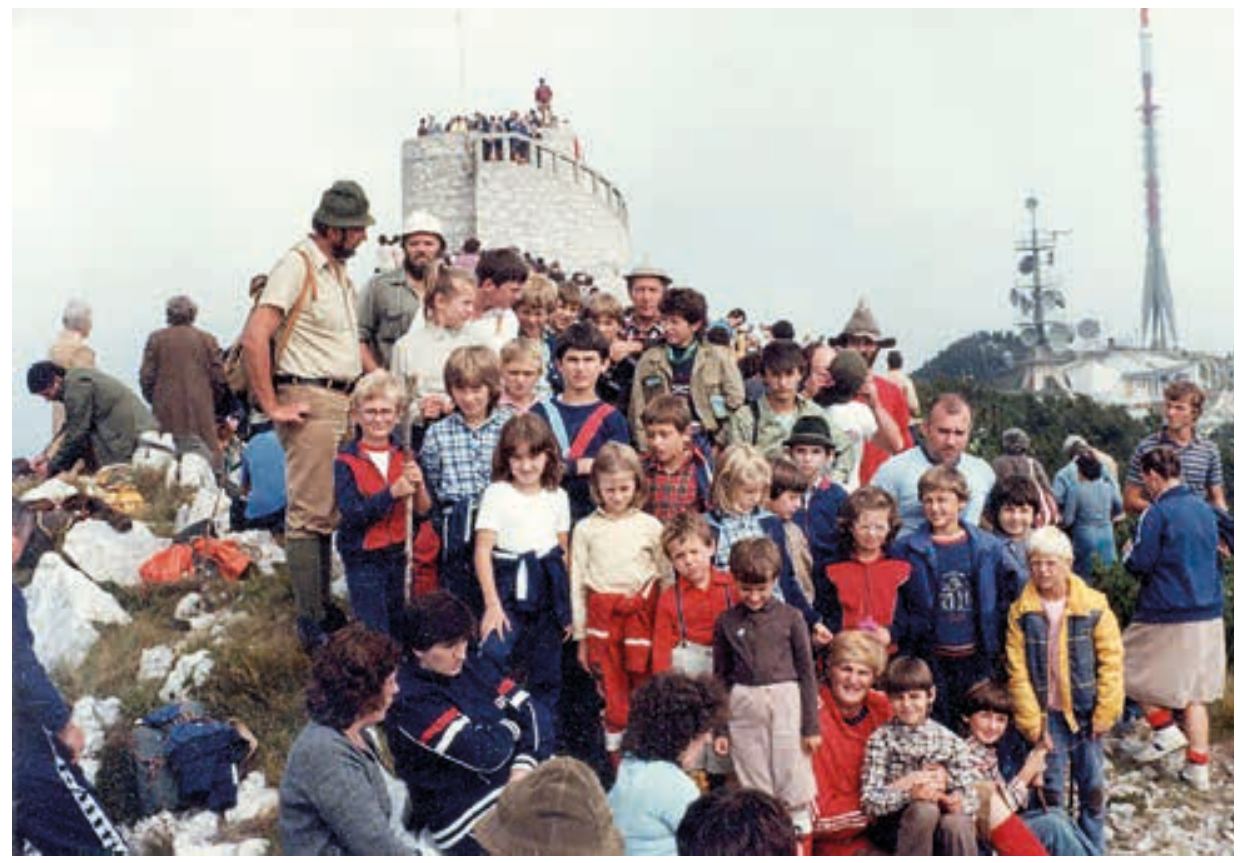

Slika 2. Članovi Planinarskoga društva „Orljak“ na Vojaku, 9. rujna 1984. Arhiva Radovana Trinajstića.

Figure 2. Members of the Mountaineering Club „Orljak“ on Vojak, September 9, 1984. Radovan Trinajstić's archive. 


\section{Osnivanje Planinarskoga društva „Orljak“ i početni uzlet 1980-ih}

\subsection{Priprema za osnivačku skupštinu i osnivanje Društva}

Dana 20. 2. 1984. poslan je uredno datiran, brojem spisa označen (19/84) i žigom Planinarskoga aktiva „Orljak“ ovjeren (u potpisu samo: Inicijativni odbor P. A. „Orljak“) pojedinačno, na ime svakog člana Aktiva poziv „da dana 29. 2. 1984. u 17.00 sati neizostavno prisustvuje MASOVNOM sastanku planinarskog aktiva „ORLJAK“ koji će se održati u društvenoj sali Vatrogasnog doma Opatija“, a sa sljedećim dnevnim redom: 1 . Priprema za osnivanje planinarskog društva; 2. Upoznavanje sa Statutom; 3. Predlaganje kandidata za tijela Društva; 4. Izvještaj o dosadašnjem radu i 5. Razno. Na kraju je poziv da se pozovu slobodno prijatelji da se uključe i učlane u buduće planinarsko društvo. (RT Inicijativni odbor P. A. „Orljak“ 1984.).

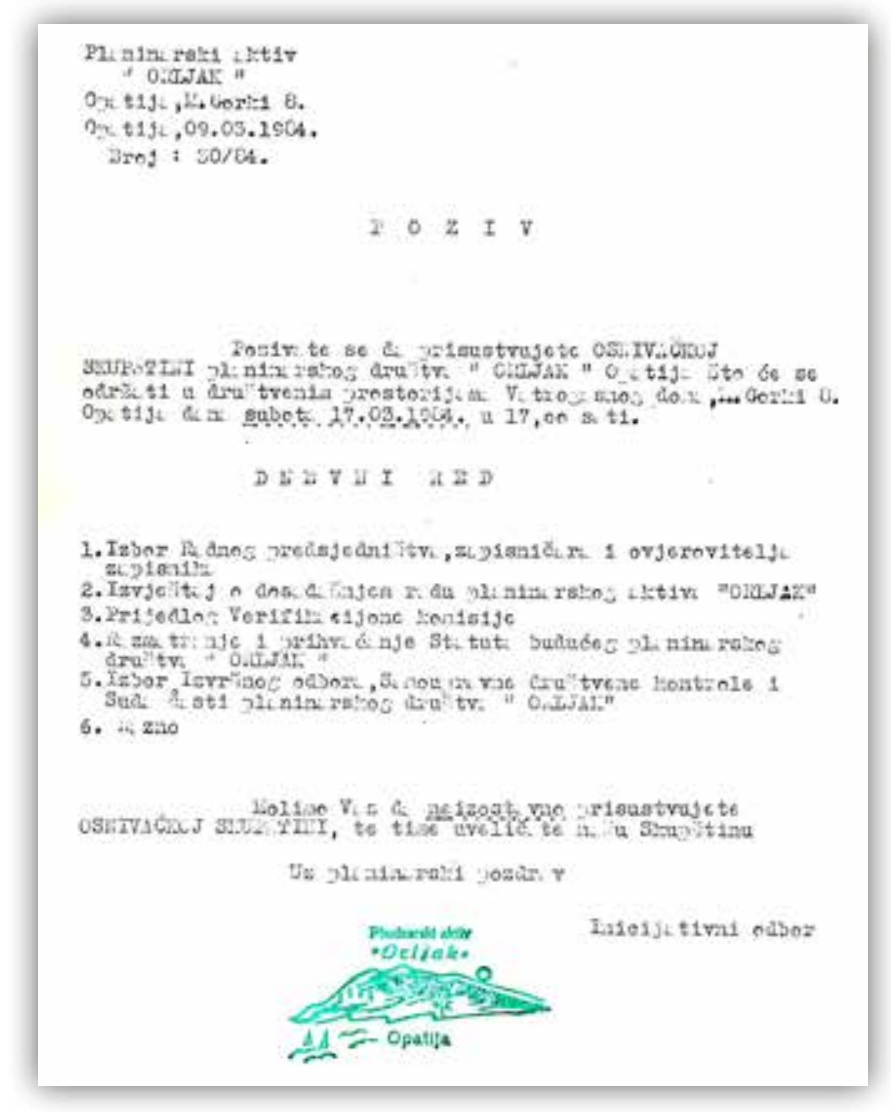

Slika 3. Poziv Inicijativnoga odbora na osnivačku skupštinu Planinarskoga društva „Orljak“. Arhiva Hrvatskoga planinarskog saveza.

Figure 3. Invitation of the Initiative Committee to the founding assembly of the Mountaineering Club "Orljak". Archives of the Croatian Mountaineering Association. 
Iz toga je poziva jasno da ideja postoji već duže jer je statut bio očito pripremljen ili u završnoj fazi pripreme, da se ozbiljno razmišljalo o Društvu i potencijalno o kandidatima za tijela koja bi to Društvo vodila. Sastanak Inicijativnoga odbora očigledno je bio uspješan jer već za nekoliko dana slijedi novi dopis (poziva) jednako uredno napisan, datiran (9. 3. 1984.) i obrojčen (30/84), i to poziv na osnivačku skupštinu Planinarskoga društva „Orljak“ (dalje: Društvo) 17. 3. 1984. godine, sa svim potrebnim točkama dnevnog reda za osnivanje nove udruge. U potpis je stavljeno samo: Inicijativni odbor (RT Inicijativni odbor 1984.).
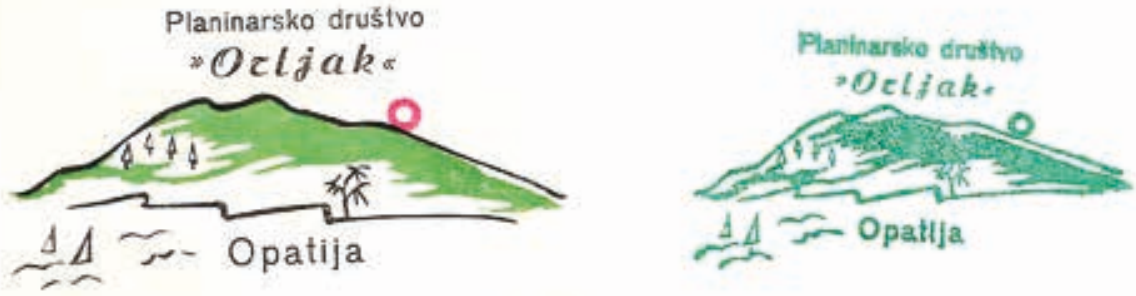

Slika 4. Znak i pečat Planinarskoga društva „Orljak“. Arhiva Radovana Trinajstića.

Figure 4. Logo and stamp of the Mountaineering Club „Orljak“. Radovan Trinajstić's archive.

Osnivanje Društva popraćeno je vijestima objavljenim u lokalnim i nacionalnim listovima, u kojima se izvještava o održanoj osnivačkoj skupštini i izabranome vodstvu. Tako doznajemo da su nakon referata o dosadašnjoj aktivnosti Aktiva i jednoglasna prihvaćanja Statuta Društva za članove Izvršnoga odbora izabrani Vladimir Lelas, Lucijan Slavić, Anton Šorić, Marijan Rubeša, Radovan Trinajstić, Sandra Ujčić, Lorenzo Selan, Ivica Rubeša, Teodora Slavić, Zoran Rubeša i Anita Paliska (Trinajstić 1984b, 1984c). Posebno je važna vijest o programu i postavljenim ciljevima, koji će obilježiti čitavo daljnje djelovanje Društva:

Na skupštini je prihvaćen okvirni program rada u kojemu je poseban akcenat na okupljanju mladih, na sudjelovanju na manifestacijama u sklopu obilježavanja prigodnih jubileja i proslava i na što većem propagiranju planinarstva među radnim ljudima opatijske komune. (Trinajstić 1984b)

Spomenuti sastav Izvršnoga odbora, kao i popis osoba ovlaštenih za zastupanje - Lucijan Slavić kao predsjednik te Marijan Rubeša kao tajnik I i Lorenzo Selan kao tajnik II - nalazimo i u službenome Zahtjevu za upis u registar društvenih organizacija (UO-OP Zahtjev 1984), koji je poslan nadležnim tijelima 10 dana nakon osnivačke skupštine, 27. 3. 1984, kako stoji u Rješenju o upisu u Registar društvenih organizacija općine Opatija donesenu 14. travnja 1984. (UO-OP Rješenje 1984). Posebno su važni prilozi spomenutom Zahtjevu, koji donose obilje informacija. Zapisnik sa skupštine prilično detaljno prenosi njezin tijek: nakon otvaranja skupštine od strane Marijana Rubeše i prijedloga dnevnog reda, koji je usvojen, rad je nastavljen po točkama. Najprije je donesena 
odluka o osnivanju novog društva s imenovanjem 12 osnivača Društva, koji su svi redom popisani u zasebnu privitku, i to ovim redom: Lucijan Slavić, Anton Šorić, Marijan Rubeša, Radovan Trinajstić, Sergije Frlan, Lorenzo Selan, Boris Križan, Zdravko Kalčić, Ivica Rubeša, Anita Paliska, Teodora Slavić i Milivoj Rubinić (UO-OP Zahtjev 1984). Nakon toga je Marijan Rubeša podnio izvještaj o radu Aktiva od osnivanja 12. 10. 1980. do 25. 2. 1984., za koje se navodi da je u privitku, ali nije pronađeno, nažalost. Slijedilo je predlaganje, raspravljanje, dopuna i naposljetku usvajanje statuta Društva te poslije toga glasanje o upravnim tijelima. Skupština je zaključena riječima uzvanika jer se pod točkom Razno nitko nije javio. Prenesene su riječi gostiju, a od uzvanika su govorili predstavnik Planinarskoga saveza Hrvatske Stanko Vičić, predsjednica Planinarskoga društva „Opatija“ Edita Majorinc, predstavnik Općinskoga planinarskog saveza Miljenko Pavešić, predstavnik Komisije za rad s omladinom Općinske konferencije Socijalističkog saveza radnog naroda Opatija Baldo Stanta, predstavnik Odreda izviđača Opatija ${ }^{9}$, predstavnik Planinarskoga društva „Željezničar“ Josip Sakoman, tajnik Turističkoga društva Opatija Božidar Vlah i predstavnik Planinarskoga društva „PTT Učka“ Rijeka Jovan Nikolić. Predsjedavajući na skupštini bio je Radovan Trinajstić, a ovjerovitelji zapisnika Anita Paliska i Anton Šorić, svi uredno potpisani (UO-OP Zahtjev 1984).

Iako izvještaj o radu Aktiva nije pronađen u prilogu Zahtjevu, srećom postoji vijest objavljena u Našim planinama, za koju se može s priličnom sigurnošću tvrditi da je riječ o članku nastalu na temelju toga izvještaja s obzirom na to da je objavljena na istoj stranici kao i vijest o osnivanju Društva, a koju je pisao isti autor na temelju zapisnika sa skupštine kojom je predsjedao. U njoj se sažeto sumira samo aktivnost Aktiva u prethodnoj, 1983. godini, gdje je već jasno vidljivo opredjeljenje za snažniji zamah u obilasku transverzala, sudjelovanje na orijentacijskim natjecanjima, obilježavanje pojedinih važnih datuma i popularizaciju planinarstva:

Iako brojčano mali, aktiv je zabilježio lani značajne akcije. Njegovi članovi sudjelovali su na orijentacionom takmičenju ,Janko Mišicic u Samoboru, takmičenju „Torpedo“ na Lisini i „Ivici Židov“ također na Lisini. Pored toga zabilježeni su i mnogi planinarski pohodi transverzalama, kao što su: kružni planinarski put kroz Samoborsko gorje, Jaskanska transverzala, Istarska transverzala, Koprivnički planinarski put i Put Kalničkih partizana. Članovi su se aktivno uključili u proslavu Dana 1. maja na Orljaku kao i u bratski susret „Bilogora ' 83 “. Sve će to pridonijeti daljnjem radu i popularizaciji planina. Aktiv se usmjerio također u pravcu svestrane suradnje s ostalim društvima i organizacijama na području općine Opatija, što pridonosi da se o planinarima sve to više razgovara i uključuje u razne društveno-političke i sportske manifestacije na području opatijske komune (Trinajstić 1984j).

9 Nažalost, u uvodnome popisu gostiju na početku zapisnika nije naveden ovaj predstavnik ni njegovo ime. Od gostiju se još jedino navodi predstavnik Općinske konferencije Narodne omladine Opatija Franjo Šarčević pa je eventualno riječ o njemu uslijed navođenja u komplementarnoj funkciji. 
Zahtjevu su priložene i dvije odluke: ona o održavanju masovnog sastanka Aktiva 19. 2. 1984. s popisom predloženih osnivača (UO-OP Odluka 1984a) te ona o održavanju osnivačke skupštine 17. 3. 1984., na kojoj su ti osnivači imenovani od strane skupštine (UO-OP Odluka 1984b). Obje su potpisane od strane Marijana Rubeše, prva u svojstvu predsjedavajućeg na masovnome sastanku Planinarskoga aktiva „Orljak“, a druga u svojstvu tajnika Planinarskoga društva „Orljak“ (UO-OP Odluka 1984a; Odluka 1984b).

Statut je također bio obvezan prilog zahtjevu, a koji je srećom sačuvan u potpunosti i vrelo je podataka o počecima rada Društva. Zanimljivo je da nema definiranja znaka Društva, što će se dogoditi tek mnogo kasnije donošenjem novoga statuta, ali statut sadrži sve uobičajene potrebne pasuse za funkcioniranje udruge. Izuzevši brojne točke koje su više-manje formalne naravi, treba izdvojiti one sadržajno bitne. Sjedište Društva bilo je na opatijskoj adresi Maksima Gorkog 8, a za predstavljanje su bili ovlašteni predsjednik i tajnik (Statut 1984: 2). Eksplicitno se u djelatnostima ističe da se aktivnosti ostvaruju okupljanjem prije svega „radnika Profesionalne vatrogasne postrojbe i članova Dobrovoljnog vatrogasnog društva Opatija“, da je u fokusu ,preventivno djelovati na čuvanju šuma od požara“ $i$,osposobljavanje [...] na veće fizičke napore u svrhu protupožarne zaštite“ (Statut 1984: 3), čime je otvoreno iskazana poveznica s vatrogasnim jedinicama. Ostali su članci Statuta uglavnom manje zanimljivi jer su uobičajeni (prava i dužnosti članova, tijela itd.), no neki su vrlo specifični i zato važni jer govore o specifičnu usmjerenju djelovanja nove udruge. Tako je važno da je već u Statutu naveden rad nekoliko stalnih komisija koje bi trebale biti produžena ruka Izvršnom odboru: 1) za transverzale; 2) za orijentaciju; 3) za izlete; 4) za suradnju s društveno-političkim organizacijama; 5) za dogovor o korištenju domova i objekata (UO-OP Statut 1984: 13). Dok je treća u sprezi s petom važna kao temeljni stup djelovanja svakoga Društva, a to su organizacije planinarskih izleta, ostale tri treba prokomentirati. Već ranije spomenuti novi smjerovi koji su Aktiv i odveli u samostalnost sada su kroz te komisije, koje bi se danas nazivale sekcije ili odsjeci, a predstavljaju temelj rada svakoga planinarskog društva, potpuno jasno izražene. Sustavan obilazak planinarskih transverzala i orijentacijski sport stavljeni su u rang najvažnijih preokupacija i aktivnosti Društva, dok se zanemariti ne smije ni suradnja s ostalim društveno-političkim organizacijama, bez koje je nemoguće osigurati dovoljno sredstava za funkcioniranje Društva. Upravo u tome treba možda tražiti razloge toliko brojnim uključenjima u proslave i jubileje s jasnim političkim predznakom, bilo da je riječ o memorijalima (npr. „Zastava na Orljaku“) ili obilježavanju pojedinih segmenata narodnih vrijednosti u vizuri socijalizma, kao što je emancipacija žena (npr. „Žene na Lisini“"). Jasnoća vizije i sustavnost rada rodit će zanimljivu i bogatu, prije svega društvenu, angažiranost i aktivnost Društva u narednim godinama.

U vijestima sa skupštine donesenima na drugome mjestu saznajemo da je odlučeno „da se u društvenim prostorijama koje se nalaze u zgradi DVD Maksima Gorkog 8 u Opatiji u Opatiji organizira dežurstvo od 17 do 19 sati radi 
upisivanja novih članova u društvo ili za dobivanje potrebnih informacija koje su vezane uz aktivnosti planinara." (Trinajstić 1984c) Uz bitne informacije o adresi (društvenim prostorijama) i uredovnom vremenu Društva, vrlo je važno istaknuti neprocjenjivu podršku opatijskih vatrogasaca. Naime zahvaljujući njima Društvo je imalo važnu logističku podršku ne samo po pitanju prostorija, već i za organizaciju većih pohoda (npr. obilasci transverzala, često djelomično i po šumskim cestama zahvaljujući vatrogasnom kombiju), mogućnost komuniciranja s drugim organizacijama i društvima (M. Rubeša radio je na vatrogasnoj centrali uz mogućnost korištenja telefona). Mnogi članovi aktivne jezgre Društva stoga jasno ističu da je Društvo moglo ne samo opstati nego i prosperirati sve dok je bilo razumijevanja i potpore vatrogasaca te napose osobne podrške komandanta Lucijana Slavića (Trinajstić 2021; Miletić 2021).

\subsection{Počeci rada Društva (1984.-1986.)}

Planinarsko društvo „Orljak“ odmah nastavlja s intenzivnim radom koji je i kao Aktiv njegovalo. U informacijama zgusnutu članku koji je objavljen u ljetnome dvobroju Naših planina doznajemo pregršt važnih informacija o radu Društva: organiziran je izlet u Samoborsko i Žumberačko gorje, članovi u pohodu obilaze točke pojedine transverzale (konkretno, Karlovačke), neki članovi sudjeluju u natjecanju iz orijentacijskog trčanja „Samobor 84“, Društvo je ponovno obilježilo na tradicionalni način prvomajsku svečanost na Orljaku (logor, cvijeće na spomeniku, paljenje krijesa i vatromet, podizanje crvene zastave), navedeno je da su u okviru boravka na Orljaku obnovljene i markacije planinarske staze koja ide od Opatije preko Bregi na vrh Orljaka, a da ih u svečanosti nije omela ni kiša ni loše vrijeme koje ih je pratilo (Trinajstić 1984d, 1984e, 1984f).

U srpnju iste godine nastavlja se aktivnost organizacijom prvoga marša partizanskim stazama „u povodu Dana ustanka naroda SR Hrvatske, 27. srpnja“, a na kojemu je uz 15 članova Planinarskoga društva „Orljak“ sudjelovalo i 20 članova izviđačkog odreda „Mate Balota“ iz Matulja i 4 člana Planinarskoga društva „Opatija“. Išlo se od Matulja do obronaka Lisine, pri čemu su posjećena spomen-obilježja Narodnooslobodilačkoga rata (Trinajstić 1984g). Ovdje treba apostrofirati posebno dobru suradnju s izviđačima, s kojima su članovi Društva na neki način i dijelili svjetonazor (Trinajstić 2021). Na drugome mjestu doznajemo detaljnu trasu pohoda koji je išao „kroz Trtne, Štranjgu, Grdi Žleb te Kućele i Škrapnu“, sama proslava je održana u Lisini (kod planinarskoga doma), a sudionici su „za uspomenu na ovaj marš dobili [...] prigodne spomen-potvrde koje će postati tradicionalne. Nakon prikupljenog određenog broja ovakvih spomen-potvrdi pojedinac dobit će jubilarnu značku organizatora budućih marševa“ (Trinajstić 1984h).

U istome članku donosi se i nešto opširnije izvješće, koje zbog škrtosti povijesnih vrela o službenim izletima Društva vrijedi donijeti u cijelosti, a osim toga vrlo su indikativne lokacije koje odražavaju sustavnost obilazaka društve- 
nih „transverzalaca“, ovdje konkretno Slovensku planinsku pot, Istarski planinarski put i Goranski planinarski put, gdje napose vrijedi istaknuti višednevnost brojnih izleta:

Od 13. do 15. srpnja članovi ovog društva bili su na izletu po Julijskim Alpama, kojom prilikom su posjetili i razgledali partizansku spomen-bolnicu „Franja“, vrh Prestreljnika na Kaninu, Vršić, Aljažov dom na Triglavu ${ }^{10}$ i Bled. Članovi društva, propješačili su planinarskom trasom Račja Vas - Orljak - Brajkov vrh - Planik - Opatija. Na taj način su djelomično ostvarili i predviđen put predjelima gdje su kontrolne točke u sklopu istarskog planinarskog puta „Labinska republika“ - Slavnik - Učka.

Planinari „Orljaka“ pošli su i na „Put prijateljstva“ Snežnik - Snježnik. $\mathrm{Na}$ tom trodnevnom pohodu posjetili su kontrolne točke Snežnik - Sežanje - Klanska polica - Šverda - Gušlica ${ }^{11}$. To ipak nije bilo dovoljno da s uspjehom obave cijeli taj transverzalski planinarski put, jer su to onemogućile loše vremenske prilike, pa će pohod morati biti ponovljen drugom prilikom (Trinajstić 1984h).

Društvo se uključuje i u tuđe izlete, pohode i proslave već od samih početaka pa tako nalazimo da opatijski planinari, članovi obaju opatijskih planinarskih društava, sudjeluju u pohodu organiziranom od strane Planinarskoga društva „Kamenjak“ Rijeka u spomen na Pazinske (rujanske) odluke o sjedinjenju Istre s maticom domovinom (Trinajstić 1984i). Na istome mjestu doznajemo i vrlo važnu informaciju o planu formiranja novoga aktiva Društva: „[t]reba istaći da su s opatijskim planinarima po prvi puta boravila 22 planinara iz Klane koji će uskoro osnovati aktiv opatijskog društva 'Orljak' u Klani“ (Trinajstić 1984i). Društvo također sudjeluje i na središnjoj proslavi 110. godišnjice organiziranoga planinarstva u Hrvatskoj, koja je održana na Medvednici, pri čemu je 12 članova posjetilo „najznačajnija planinarska mjesta na Medvednici, djelomično izvršili obilazak planinarske transverzale 'Planinarski put Medvednicom', te prošli kroz sve točke, čime su osvojili spomen-transverzalske značke koje dobije samo onaj planinar koji propješači cijeli put transverzale“" (Trinajstić 1984k). Uz to što su vrijeme iskoristili za upoznavanje planinara iz svih krajeva zemlje, članovi Društva uspjeli su dakle završiti jednu od započetih transverzala, što svjedoči o sustavnosti i predanosti grupe transverzalaca u Društvu. Članovi obaju opatijskih planinarskih društava uključuju se također u XXI. jubilarni susret planinara PTT-a Hrvatske, koji je organiziralo u Opatiji Planinarsko društvo „Sljeme“ Zagreb od 28. 11. do 2. 12. 1984., a u okviru 110. obljetnice planinarstva u Hrvatskoj (Blažević 1984).

Članovi Društva često su bili angažirani na masovnim skupovima i marševima kao vodiči. Tu se posebno ističe njihovo sudjelovanje kao vodiča u masovnim marševima na Učku od samih početaka rada. Primjerice $u$ tradicionalnom

10 U članku je pogrešno napisano - trebalo bi pisati Aljažev dom pod Triglavom.

11 Zanimljiv je zapisani oblik, koji se često čuje među starijim planinarima, dok je na kartama toponim naveden u liku Guslica. 
maršu „Učka '84'“, održanu 7. travnja 1984. (Halilović 1984), kao vodiči 300 sudionika marša, pretežno mladih, iz Društva su angažirani Sandra Ujčić, Milan Mudrovčić, Lorenzo ${ }^{12}$ Selan, Ivica Rubeša, Damir Batistić i Zoran Rubeša (Stanta 1984b).

I sljedeće godine Društvo nastavlja s izletima i izvještavanjima o njima u medijima. Tako saznajemo da je

Planinarsko društvo „Orljak“ iz Opatije organiziralo za članove društva jednodnevni izlet. Posjetili su Škocijansku ${ }^{13}$ jamu, Predjamski grad i Cerkniško jezero. Na izletu su bila 22 planinara od toga 14 mladih.

Lijep sunčan dan omogućio je izletnicima da se u prirodi zabave, a ujedno su mladi upoznati sa aktivnostima planinarske organizacije. Izletom su bili obuhvaćeni i mlađi članovi planinarskog društva iz Klane, koje djeluje kao ogranak opatijskog društva „Orljak“ (Trinajstić 1985a).

Posebno je važna informacija o pretežno mlađim sudionicima na izletima te sve aktivnijem aktivu iz Klane koji djeluje u okviru Društva.

Godine 1985. Društvo organizira jednodnodnevni izlet na Matić-poljanu u okviru 23. memorijala „26 smrznutih partizana“, a doznajemo da je na „izletu bilo 18 planinara, od toga 9 mladih“ (Trinajstić 1985b).

Prva godišnja skupština održana je početkom 1985. godine u prostorijama vatrogasnoga društva, a u izvješću iz medija saznajemo da je izvješće o radu Društva podnio tajnik Marijan Rubeša, pri čemu se u protekloj godini ističe organizacija 19 jednodnevnih izleta, 3 dvodnevna izleta, 5 trodnevnih izleta, sudjelovanje u jednodnevnoj radnoj akciji sadnje crnogorice na padinama Planika i Ružmanjca (organiziralo Lovačko društvo „Lane“ Opatija), šestodnevno zimovanje u lovačkoj kući „Brdo“ (vlasnik Lovačko društvo „Lane“ Opatija), grupa transverzalaca uspješno je završila nekoliko transverzalskih pohoda i osvojila ukupno 31 značku, ekipa orijentacista sudjelovala je na 4 orijentacijska natjecanja, a članovi Društva uključili su se u raznorazne manifestacije, pa su tako pripomogli uspješnoj organizaciji maskirane povorke, jedriličarske regate i Kupa Opatije te sudjelovali u humanitarnim akcijama Crvenog križa Opatija. Postignuta je suradnja s brojnim organizacijama i društvima, no posebno se ističe da Društvo ,svesrdnu pomoć dobiva od Profesionalne vatrogasne jedinice Opatija, Štaba TO ${ }^{14}$ Opatija, Općinskog odbora Crvenog križa Opatija, Turističkog društva Opatija i Općinskog sindikalnog vijeća Opatija.“ (Trinajstić 1985c; 1985h) Iz istoga izvora saznajemo i pregršt drugih važnih informacija, prije svega da Društvo „danas broji 135 članova [što je] znatan porast u odnosu na dan osnivanja. U društvu je osnovan i aktiv koji djeluje u Klani, sa 40 članova, mahom mladih. Od samog osnivanja velika se pažnja posvećuje mladima koji zasada u društvu čine većinu.“( (Trinajstić 1985c; 1985h)

12 U članku je pogrešno napisano Lorenco (Stanta 1984b).

13 U članku je pogrešno napisano - trebalo bi pisati Škocjansku.

14 Teritorijalna obrana. 
Treba istaknuti da je i osnivanje aktiva u Klani pokrenuto uslijed premreženosti između vatrogasaca i planinara, o čemu opširno izvještava Mario Rubeša:

Ideja o osnivanju planinarskog aktiva „Klana“ nikla je prilikom izleta koji je organiziralo PD „Orljak“ od 13. do 15. srpnja 1984. po Julijskim Alpama u kome je sudjelovalo i nekoliko Klanjaca. Omasovljenje je uzelo maha u rujnu 1984. kada se aktivu „Klana“ priključio priličan broj djece njhovih roditelja za sudjelovanje na Memorijalnom pohodu na Učku. Danas aktiv broji 46 članova. Organizirali su samostalno 6 izleta, a sudjelovali su u izletima PD „Orljak“ u tri navrata, čak sa dvije trećine članova. (Rubeša 1985f)

Članovi Društva uzvratili su pak sudjelovanjem u akcijama DVD-a Klana i time je zatvoren krug tješnje povezanosti, a pri „,tome svakako treba istaknuti veliko zalaganje Borisa Križana i Viktora Gržinčića, koji su glavni nosioci planinarske i vatrogasne aktivnosti među članovima." (Rubeša 1985f)

Društvo je i 1985. angažirano za vođenje na maršu „Učka '85“, pri čemu je ostao zapis o 280 mladih koji su došli iz cijele Hrvatske i uspješno se od Ičića na samome moru popeli na Učku, dok su njihovi vodiči bili upravo Željko Rubeša, Zoran Rubeša i Sandra Ujčić iz Planinarskoga društva „Orljak“ (Trinajstić 1985d, 1985e).

Društvo najavljuje iste godine niz planinarskih susreta i prigodnih proslava tijekom cijele godine povodom 100. obljetnice planinarstva na području opatijske rivijere (Trinajstić 1985f, 1985g), od kojih neka slijede u nastavku. Tako je proslava „Zastava na Orljaku“ bila ove godine nešto bogatija, pa je uz tradicionalni logor, krijes i podizanje zastave tom prilikom svečanost bila posebna zbog postavljanja metalnoga žiga na vrhu Orljaka, a čemu su prisustvovali i gosti iz Planinarskoga društva „Koprivnica“ Bugojno te je od strane Društva organizirana i prodaja ,razglednica s opatijskim motivima, a izdana je i jubilarna značka i prigodni pečat" (Rubeša 1985b). O tome se izvještava i na nacionalnoj razini (Trinajstić 19851).

O posjeti planinara iz Bugojna te o prijateljskim vezama s Planinarskim društvom „Koprivnica“ opširnije piše u istome broju Opatijske komune u opširnijem članku, gdje se izvještava o vrlo lijepu domaćinstvu Društva, čiji su članovi svoje planinarske prijatelje ugostili i na logoru na Orljaku pri proslavi prvomajske svečanosti, vodili ih Učkom, posjetili s njima Planinarski dom „Poklon" te ih proveli ne samo zaleđem Lovrana i Opatije već i obalnim mjestima (Rubeša 1985c).

Posebno značenje ima postavljanje metalnih žigova, čime je Društvo uz stalno markiranje ostavilo najznačajniji trajan trag na planinarskim stazama u području Lisine. Tako je o postavljanju žiga na Orljak pisano zasebno na drugome mjestu, gdje se navodi da je svečano otkriven žig na vrhu Orljaka 30. 4. 1985. u 21:45 sati. Postavljen je od strane Društva, a u suradnji s Turističkim savezom općine Opatija, pri čemu se ističe da je to ,prvi takav pečat na području Hrvatskog primorja i Istre.“ Autor ističe kako treba cijeniti rad markacista te da je „,[p]okazati veću brigu za čuvanje skupih metalnih cilindara, kutija i pečata izraz [...] našeg 
poštovanja planinarima - entuzijastima koji ulažu mnogo truda za osiguravanje i postavljanje pečata, markica, upisnih bilježnica, a posebno za markiranje puteva i staza na terenu. Poštivanjem planinarske etike pridonosi se obogaćivanju izletišta, ne samo vrijednim pečatima, već i putokazima, preglednim panoima i drugim oznakama. " (Rubeša 1985d) Rubešin poziv na čuvanje planinarske infrastrukture kao dio planinarske etike nije ništa manje aktualan ni danas.

Žig je Društvo uskoro postavilo i na Crnom vrhu (1037 m), o čemu je opširno izvijestio Marijan Rubeša. Saznajemo da je žig postavljen od strane Društva „[u] povodu Dana Republike, 40. obljetnice pobjede nad fašizmom i 100. obljetnice planinarstva na opatijskoj rivijeri“, ponovno „u suradnji sa Turističkim društvom Opatija“ te da je to „za sada drugi takav pečat u Hrvatskom primorju.“ (Rubeša 1985g) Rubeša ponovno poziva na čuvanje planinarske infrastrukture žigova, metalnih kutija i upisnih knjiga - no sada proširuje svoj apel i upozorava na važnost generalne planinarske infrastrukture o kojoj brižno skrbe markacisti:

Istovremeno bi trebalo posvetiti više pažnje očuvanju markacija i markiranih staza i puteva, kako se ne bi nemilosrdno obarala stabla, razrivale planinarske staze i putevi. Trebalo bi se ugledati u susjednu Sloveniju u kojoj se poštuju markacije, markirane staze, putokazi i obilježja koja su postavljena. Markacije su sačuvane i na suhom drvu koje je već odavno moralo bit porušeno i korišteno za ogrjev. (Rubeša 1985g)

Rubešine misli, iako uz ponešto romantiziran pogled na naše planinarske susjede, traži odgovarajući uzor u Sloveniji kao izrazito planinskoj zemlji, gdje planinarstvo ima posve drugačiji status, a u skladu s time razvijena je i visoka planinarska kultura, ne samo etika. Rubeša je iskoristio visoku obljetnicu u okviru koje su markacisti Društva postavili prva dva metalna žiga na području opatijskog zaleđa da promovira planinarstvo i planinarske vrednote, odnosno opću kulturu ponašanja u prirodi i poštovanja tuđeg truda i zalaganja. Te su Rubešine misli sve aktualnije $u$ vremenu kada se u sredinama poput Opatije planinari bore s raznim faktorima koji nemilice uništavaju planinarsku infrastrukturu, a najvažnije je spomenuo sam Rubeša: bjesomučno obaranje stabala i razrivanje lijepih i ugodnih planinarskih šumskih staza koje se pretvaraju u blatnjave, neugledne šumske vlake i ceste na mjestima opatijskog zaleđa s rijetkim preostalim područjima uređenih, markiranih šumskih staza u gotovo netaknutoj divljini. ${ }^{15}$ Postavljanje žigova na Orljaku, odnosno Crnom vrhu predstavljeno je i u službenome glasilu Planinarskoga saveza Hrvatske (Trinajstić 1985j, Rubeša 1985h).

U zasebnom članku Marijan - Mario, kako se inače potpisuje i kako su ga zvali - Rubeša izvještava o uključenju Društva u natjecanja iz Prve pomoći - to

15 Možda je najbolji primjer, samo da se fokusiramo na trasu Opatijske planinarske obilaznice, čijim je osnivačem i upravljačem Planinarsko društvo „Opatija“, nedavno pustošenje šume na prilazu Zvoncevom vrhu (972 m) iz smjera Veprinca s potpuno izostalim senzibilitetom za markacije na stablima, a da se o razrivanju putova i ne govori. Slično je učinjeno godinu-dvije ranije na prilazu Brložniku (1093 m) itd. Nažalost, podizanje planinarske kulture i okolišne etike ostaje i dalje nešto što naše društvo očito tek mora polagano dostizati. 
je početak dugogodišnjega uspješnog sudjelovanja Društva u sličnim natjecanjima: ${ }^{16}$

Planinari društva „Orljak“ iz Opatije uključili su se u 14. općinsko natjecanje u pružanju prve pomoći. Natjecateljsku ekipu planinara - omladinaca predstavljali su Sandra Ujčić (vođa ekipe), Damir Tumpić (zamjenik vođe ekipe) i članovi Senka Salopek, Sandra Karabajić, Jadranka Batistić i Zoran Rubeša. Ekipa je osvojila II. mjesto [...]. Postignuti rezultat za desetinku je slabiji od prvoplasirane ekipe [...]. (Rubeša 1985e)

Drugi autor u izvještavanju o istome natjecanju napominje da su grupu omladinaca Društva u ovom natjecanju predvodili (za natjecanje pripremali) stariji članovi - Mario Tumpić i Marijan Rubeša (Trinajstić 1985k), čime se svestranost tajnika Društva ponovno iskazuje.

Društvo se i dalje uključuje u manifestacije drugih društava. Primjerice 7 planinara Društva sudjeluje na susretu planinara na Snježniku u organizaciji Planinarskoga društva „Platak“ (Trinajstić 1985i), a u III. Memorijalnom pohodu na Učku u organizaciji Planinarskoga društva „Kamenjak“ Društvo se uključuje i organizacijski i kao dio planinarske grupe. Društvo je tako „organiziralo bivak u Domu 'Prve istarske čete' na Veloj Učki“, prvi dan opremajući dom s hranom i pripremajući ga za goste, od kojih su tu odsjeli uz članove Društva i „planinari P.D. 'Pazinka' iz Pazina i P.D. 'Kukavica' iz Leskovca.“ Svi su zajedno sudjelovali u programu Memorijala, a od strane Društva prisustvovalo je čak 27 planinara, ,i to 9 seniora, 8 omladinaca i 10 pionira, a od toga su dva člana bila na pohodu po treći put, dok je 18 članova drugi put na pohodu i za to su dobili zasluženo priznanje - 'brončanu značku'." (Rubeša 1985i)

Aktivnosti Društva i medijske objave o tim aktivnostima bile su vidljive i na nacionalnoj razini, stoga se u časopisu Planinarskog saveza Hrvatske Josip Sakoman osvrće i pohvaljuje ovu visoku aktivnost mladoga planinarskog društva (Sakoman 1985).

Drugi je marš „Partizanskim stazama“ Društvo organiziralo 27. srpnja od Pilane do doma na Lisini, kako doznajemo iz najave u medijima (Rubeša 1985j), a u toj svečarskoj 1985. godini ono organizira i podjelu znački za dva sudjelovanja u marševima. Podjela je organizirana 28. studenog povodom Dana Republike u prostorijama Vatrogasnog doma Opatija, a kao priznanje sudionicima. Bilo je vrlo svečano s nizom gostiju iz političkoga, planinarskoga i kulturnoga života Opatije i Rijeke, a prenesene su i neke od pohvalnih pozdravnih riječi gostiju za

16 Društvo je dugi niz godina ostvarivalo zapažene uspjehe u općinskim natjecanjima u pružanju prve pomoći. Tako ekipa omladine 1985. u sastavu Jadranka Tumpić, Senka Salopek, Tatjana Zalović, Zoran Rubeša, Damir Batistić i Sandra Ujčić osvaja II. mjesto; 1986. u sastavu Jadranka Tumpić, Tanja Zalović, Suzi Ilijić, Gordana Šmitran, Nataša Mihočić i Svjetlana Hent (rezerva: Sandra Karabajić) osvaja II. mjesto; 1987. u sastavu Svjetlana Hent, Aleksandra Dimitrijević, Darija Brajan, Dubravka Bečić, Janja Kocbek i Tanja Zalović (rezerva: Gordana Šmitran) osvaja III. mjesto; 1988. u sastavu Tanja Zalović, Aleksandra Dimitrijević, Jadranka Tumpić, Marina Rubeša i Sabina Hero osvaja III. mjesto (ZR Općinsko natjecanje 1985, 1986, 1987, 1988). 
aktivnost i rad Društva (Tumpić i Rubeša 1985). Time je na neki način svečano okrunjena iznimno aktivna godina Društva.

Društvo je i u sadržajnom smislu okrunilo godinu jednim jednodnevnim izletom i sedmodnevnim zimovanjem na prijelazu stare u novu godinu. Izlet na Vodičku grižu iz Rukavca održan je 30. studenog s odgovarajućom okrepom planinara na usponu i silasku u Planinarskom domu „Stanko Jurdana“ u Lisini (Rubeša 1986a).

Zimovanje je pak posebna priča, koja je bila svojevrsno obilježje Društva: višednevna druženja sa spavanjem u planini. Tako Cvjetana Miletić donosi opširan izvještaj o zimovanju, koji barem djelomično treba donijeti u izvorniku da se dočara klima i kontekst za važnost ovakvih druženja. Tako čitamo da, usprkos dugim zimskim praznicima,

malo je bilo stručno organiziranih i sadržajno bogatih aktivnosti pripremljenih od raznih društvenih ili sportskih organizacija. Zbog toga je vrijedno zabilježiti pokušaj Planinarskog društva „Orljak“ da se u novogodišnje praznike za djecu unesu novi sadržaji zabave i razonode. [...]

Tako je 20 planinara 28. prosinca 1985. krenulo na sedmodnevni boravak na Veloj Učki. Smještaj su imali osiguran u Domu „1. istarske čete“, dok su dobavu namirnica i pripremanje obroka preuzeli stariji planinari, kako bi cijena boravka na Učki bila što pristupačnija, naročito za djecu.

Dragocjenu pomoć u organizaciji i prijevozu djece, osobne i skupne opreme, pružili su Profesionalna vatrogasna jedinica Opatija, općinska organizacija Crvenog križa Opatija i radna organizacija „Mozaik“ Opatija. [...]

Svi dani bili su ispunjeni raznovrsnim igrama, natjecanjima, šetnjama, planinarenjem... Već drugog dana boravka na Učki obradovao ih je snijeg. Večernje društvene igre, glazbu s kazetofona i TV emisije zamijenili su sanjkanje i grudanje. [...]

Kada su 5. siječnja 1986. napuštali Velu Učku, svi su bili bogatiji za jedno ugodno druženje, a učenici spremniji da se lakše suoče s posljednjim provjerama znanja pred polugodište. (Miletić 1986)

Taj članak nudi pregršt važnih informacija o značaju takvih događanja. Sama činjenica da je organiziran takav sadržaj za djecu, financijski pristupačan gotovo svima, a u vremenu kad financijska kriza postoji u državi, već je dovoljna za pohvalu Društvu. Vrsta sadržaja koja je djeci omogućila boravak u prirodi, druženje, igru i zabavu daleko od civilizacijskih „blagodati“ neprocjenjiva je za njihov psihofizički razvoj, obnovu energije za školu koja predstoji i generalno stjecanje navike boravka u prirodi. Sama ideja višednevnog boravka u prirodi, vrlo bliska izviđačkom svjetonazoru, nešto je što je Društvo konstantno propagiralo i što se, nažalost, u današnjem modernom svijetu brzog života gotovo posve izgubilo u planinarstvu (to je zapravo vidljivo i u slabljenju izviđačkoga pokreta, koji je miljama daleko od one organiziranosti i aktivnosti iz 1980-ih godina prošloga stoljeća). 
Društvo ne posustaje ni sljedeće godine. Iako je aktivnosti manje, ono osniva neke nove. Jedna je od istaknutijih svakako akcija „Žene na Lisini“, koju je Društvo organiziralo zajedno s Konferencijom za društveni položaj žene i porodice Opatija 7. ožujka 1986. Kako je navedeno, „ova akcija ima za cilj da obogati sadržaje i dade poseban doprinos sveukupnim manifestacijama kojima će se ove godine obilježiti Međunarodni praznik žena i 45. obljetnica ustanka“, pri čemu su organizatori posebno pozvali radne organizacije na razumijevanje i podršku s obzirom na to da je održavanje u petak, na radni dan, pa mole da se opravda izostanak sudionicama, dok će dokaz o sudjelovanju biti izdane im naljepnice (Miletić 1986b). O samom održavanju izvještava Mirta Blažević, koja naglašava da unatoč lošem vremenu to nije omelo pedesetak žena koje su sudjelovale u pohodu da usprkos nemogućnosti posjeta lokaciji partizanske bolnice Ljubice pod Vodičkom grižom ipak posjete spomen-obilježja Narodnoslobodilačkoga rata u okolici planinarskog doma u Lisini, u kojemu je bio priređen ručak i okrepa toplim čajem za sve sudionike (Blažević 1986). Treba istaknuti da se uz članak pojavljuje očigledno pretisak prigodne naljepnice koja je dijeljena sudionicama, a u kojoj nalazimo nekadašnji znak aktiva, koji će za koju godinu novim statutom biti definiran kao znak Društva.

Nastavlja se s organiziranjem jednodnevnoga izleta povodom memorijala „26 smrznutih partizana“, a 1986. je 14 planinara iz Društva sudjelovalo na proslavi koja je održana u Mrkoplju jer je obilan snijeg onemogućio pješačenje na Matić-poljanu (Trinajstić 1986a).

Iako nije eksplicirano u najavi prvomajskih svečanosti 1986. godine, već je samo opisno navedeno da one ,počinju maršom planinara i izviđača iz Opatije do Orljaka, a nastavljaju se satom povijesti uz logorsku vatru nakon što se na vrh Orljaka i ove godine uoči praznika postavi proleterska zastava“ (Miletić 1986c), Društvo je stalan i kontinuiran nositelj organizacije marša na Orljak, postavljanja logora i podizanja zastave (Rubeša 2016; Miletić 2021). No to je eksplicitno ipak ispravljeno u izvješću o održanoj svečanosti, gdje se navodi da iz „logora planinara PD 'Orljak' koji su na Orljaku boravili četiri dana i zapalili logorsku vatru uoči praznika, te postavili proletersku zastavu da pod njom održe sat povijesti, sudionici proslave su se spustili na Zadušćinu." (Miletić 1986d: 2) Čak je i cijeli zasebni članak posvećen Društvu i organizaciji svečanosti s naglaskom na paljenje prvomajskoga krijesa (Tumpić 1986a).

I te je godine članovima Društva povjereno „da 6. travnja vodi sudionike 23. omladinskog marša 'Vrata '86 - Učka '86'. Trasa marša bila je Ičići - Brdo - Korići - Strmice - tunel Učka - Učka 'Ina'. U maršu je sudjelovalo petnaest planinara PD 'Orljak', a petorici je bilo povjereno vođenje 151 sudionika marša.“" (Rubeša 1986b) Članovi Društva opet se dokazuju kao uspješni vodiči iznimno velike grupe na uobičajenoj trasi od obale mora do danas bivšeg Inina odmarališta na Učki (podno prijevoja Poklon).

U izvješću sa skupštine 1986. godine kratko se sumira rad Društva u protekloj godini. Istaknuto je da Društvo broji 150 članova, pretežno mladih, a da 43 člana djeluju pri aktivu „Klana“; da je održan niz pohoda i izleta. Održana 
su tri izleta: Židovje - Studena - Brdo, na Pliš i kružni izlet po Istri. Članstvo je sudjelovalo na prvomajskoj svečanosti, na maršu „Partizanskim stazama“ Brdo - Lisina, nizu manjih pohoda na Platak, Matić-poljanu, Učku, Snježnik, Vodičku grižu, Crni vrh, Cerovicu, Nanos, Fužine itd. Važni su pohodi u povodu Dana boraca Žejane - Cerovica - Mune i marš u povodu Dana ustanka SR Hrvatske Brdo - Pilana - Crni vrh - Lisina te sudjelovanje na trećem pohodu planinara na Učku. Podsjetilo se na postavljanje dvaju metalnih žigova te se zahvalilo svim organizacijama bez čije pomoći ne bi bila moguća realizacija svih tih aktivnosti. Članovi Društva pomagali su u akcijama Crvenog križa, radili na markiranju i održavanju planinarskih putova, zapaženi su uspjesi transverzalaca, a sudjelovalo se i na orijentacijskim natjecanjima, iako mnogo manje negoli je planirano zbog financijskih ograničenja. U raspravi su sudjelovali isključivo gosti skupštine (Trinajstić 1986b). O skupštini je kratko informirana i šira planinarska javnost u nacionalnome planinarskom glasilu (Trinajstić 1986c).

Treba pribilježiti i sudjelovanje grupe planinara Društva na ,sedmom 'Pohodu planinara Jugoslavije' na Titov vrh u povodu Dana mladosti“" (Rubeša 1986c).

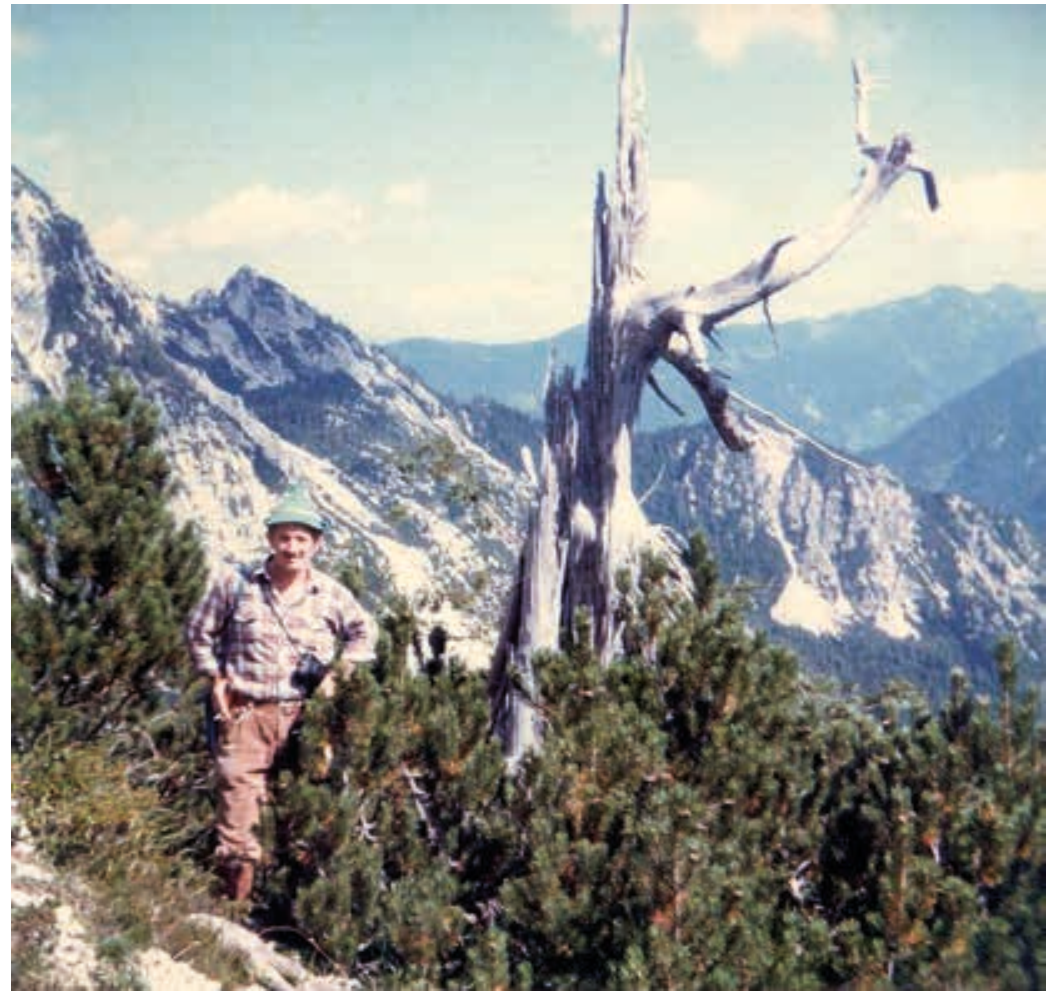

Slika 5. Marijan Rubeša u slovenskim Alpama. Arhiva Zorana Rubeše.

Figure 5. Marijan Rubeša in the Slovenian Alps. Zoran Rubeša's archive. 


\subsection{Promjene u vodstvu Društva i nove aktivnosti (1986.-1989.)}

Kako je već rečeno, o skupštini 1986. opširno je izviješteno u medijima, gdje je istaknuto da su izabrani novi članovi Izvršnog odbora te je izabran novi predsjednik (Trinajstić 1986b, 1986c). Sama skupština održana je 19. travnja 1986. (UO-OP Zahtjev 1986), kako se može iščitati prema Zahtjevu za upis izmjena i promjena, predanu nadležnim tijelima 2. lipnja 1986. (UO-OP Rješenje 1986). Kao prilog Zahtjevu predan je novi popis članova Izvršnoga odbora, gdje je vidljivo osvježenje članstva toga upravnog tijela s četiri novoizabrana člana (posljednja četiri navedena): Željko Rubeša, Mario Rubeša, Radovan Trinajstić, Ivica Rubeša, Anton Šorić, Sandra Ujčić, Zoran Rubeša, Jerko Gudac, Višnja Ružić, Eugen Čepar i Božidar Vlah (UO-OP Zahtjev 1986). Za predsjednika je izabran prijašnji član Izvršnoga odbora Željko Rubeša, a tajnik ostaje Mario (Marijan) Rubeša. Uz njih dvojicu za osobu za zastupanje ovlašten je i novi član Izvršnoga odbora Jerko Gudac posebnom odlukom, priloženom Zahtjevu (UO-OP Zahtjev 1986).

Sačuvan je podatak da su „,̌lanovi PD Orljak sudjelovali u orijentacijskim takmičenjima, no kad se sredinom osamdesetih prešlo s klasične na nordijsku (brzu or[i]jentaciju), više nije bilo interesa u Društvu.“" (Simičević 1997)

Društvo nastavlja s organizacijom marša „Partizanskim stazama“, koji ove godine kreće od Žejana preko Šije pa do doma u Lisini (Miletić 1986d; Rubeša 1986d, 1986f, 1986i), organizira ponovno i marš „Stazama NOB-a“ povodom Dana boraca 4. srpnja, čija je trasa te godine bila od prijevoja Poklon preko kanjona potoka Banina do Dobreća, koji je zbog praznika nažalost bio slabije posjećen, sa samo dvadesetak sudionika (Rubeša 1986e).

U lijepom sumarnom članku u Opatijskoj komuni tajnik Društva Marijan Rubeša koncizno navodi aktivnosti Društva tijekom ljeta. Tako se spominje podizanje logora za susrete aktivista Crvenog križa polovicom lipnja, zatim održavanje marševa „Stazama ${ }^{17}$ NOB-a“ i „Partizanskim stazama“ te posjeti planinara i transverzalaca Soči, Krnu i Krnskim jezerima, odnosno Hahliću, Obruču, Crnom vrhu i Kleku. Posljednjim vrhovima grupa transverzalaca uspješno je završila obilazak Riječke transverzale. ${ }^{18}$ Spominje se i osnivanje Planinarske družine „Ključ“ pri Teritorijalnoj obrani općine Opatija te organizirano grupno patroliranje skupine planinara u suradnji s Civilnom zaštitom kroz sve vikende u srpnju i kolovozu kao prevencija šumskih požara. U rujnu je najavljen izlet na Orljak „uz markiranje i čišćenje staza“ (Rubeša 1986g).

17 U članku se konkretno navodi kao ime marša „Putevima NOB-a“, pri čemu je očito riječ o istoznačnome nazivu za istu manifestaciju $\mathrm{s}$ obzirom na spominjanje u drugim tekstovima istoga autora.

18 Riječka je transverzala jedna od najstarijih obilaznica kod nas (otvorena 4. srpnja 1967.), a nedavno je doživjela novo rođenje u obliku Riječke planinarske obilaznice (otvorena 18. rujna 2021.) koja je uglavnom zadržala staru trasu transverzale, ali i dodala neke nove kontrolne točke. 
O spomenutoj planinarskoj družini „Ključ“ doznajemo više iz zasebnih članaka o njezinu osnivanju. Naime na redovnoj skupštini Društva donesen je zaključak da se osnuje planinarski aktiv pri Teritorijalnoj obrani i prilika za to pojavila se na maršu „Partizanskim stazama“, održanu 16. kolovoza, na kojemu su bili pripadnici Teritorijalne obrane. Kako prema novom statutu Planinarskog saveza Hrvatske nestaju aktivi, a nove jedinice nazivaju se družine, donesena je odluka o osnivanju nove planinarske družine, koja će se nazvati „Ključ“. Kako se navodi, ,[d]ružina će okupljati pripadnike Teritorijalne obrane. Samostalno će djelovati, jer se zbog specifičnosti rada i zaduženja ne mogu uključiti u redovan rad planinarskog društva 'Orljak'. Tako će imati priliku da samostalno planiraju izlete, pohode i akcije u koje će se moći uključivati i ostali članovi društva koji izraze želju da sudjeluju u pojedinim akcijama.“ (Rubeša 1986h, usp. Rubeša 1986j). Objašnjenje vezano za aktive i družine, tj. opravdanje formalnim razlozima, čudi jer je primjerice aktiv „Klana“ i dalje bio prisutan, bilo to formalno ili neformalno. Dakle razloge o nemogućnosti tješnje aktivnosti u radu Društva ipak treba tražiti u specifičnim sadržajnim razilaženjima.

Iz izvora doznajemo i detalje radne akcije markiranja i uređenja staze do Orljaka u listopadu iste godine. Željko Rubeša predvodio je grupu omladinaca i pionira, koje je učio markiranju u teoriji i praksi na terenu. Sudionici su čistili stazu, markirali i očistili logor na vrhu Orljaka, upisali se u knjigu utisaka i udarili pečat. Najavljena je nova radna akcija čišćenja i markiranja staze od Kućela do Orljaka (Tumpić 1986b).

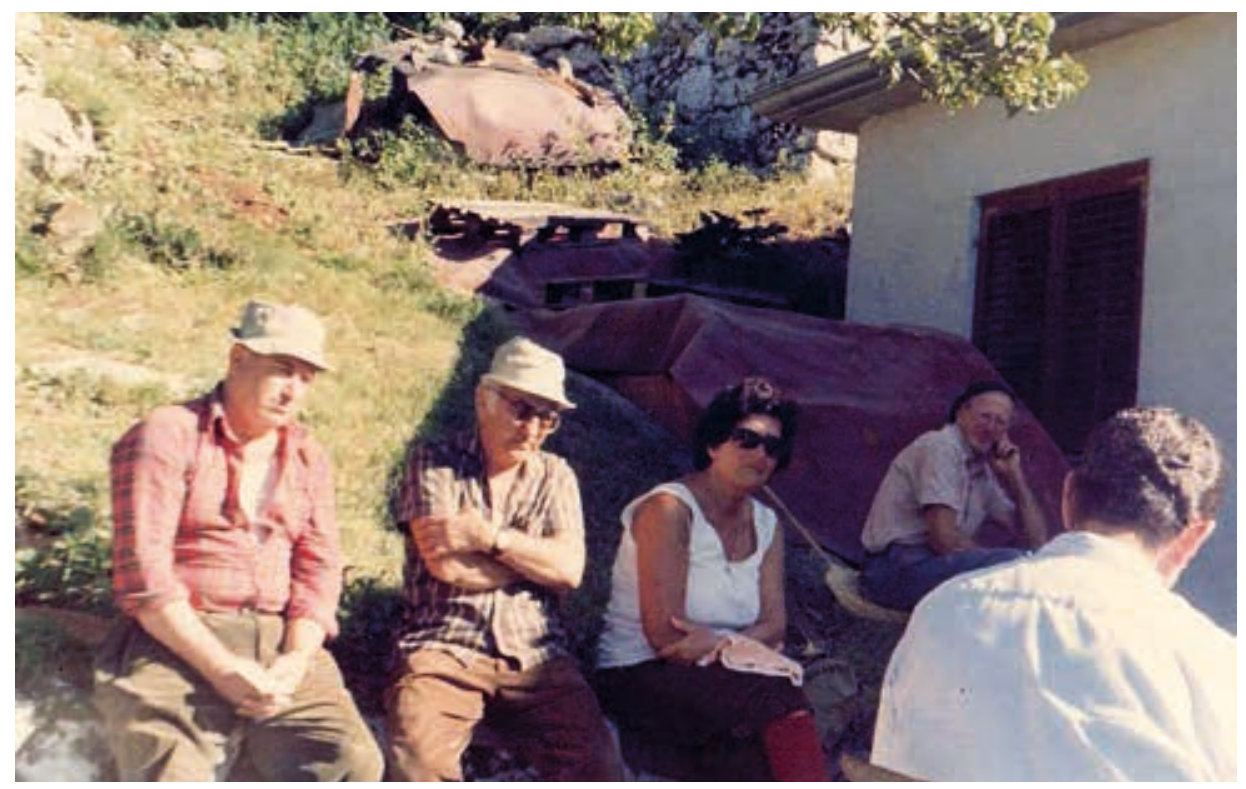

Slika 6. Lučo Rosmani, Baldo i Marija Stanta ispred Planinarskoga doma „Poklon“ (kraj 1980-ih). Arhiva Zorana Rubeše.

Figure 6. Lučo Rosmani, Baldo and Marija Stanta in front of the mountain hut „Poklon“ (end of 1980s). Zoran Rubeša's archive. 
Treba posebno izdvojiti da je Društvo krajem godine, 28. studenoga, organiziralo dodjelu priznanja svima koji su im pomagali u radu. Uručene su prigodne diplome, priznanja za sudjelovanje na marševima te zahvalnice društvenim organizacijama, između ostaloga i listu Opatijska komuna (Pažin 1986). Taj je list definitivno odigrao važnu ulogu u promociji Društva te generalno planinarstva, o čemu je dovoljno baciti pogled na popis korištenih izvora u ovome radu, što je prepoznato od strane Društva i adekvatno nagrađeno priznanjem.

$\mathrm{Na}$ prijelazu u novu godinu Društvo ponovno organizira zimovanje, toga puta nešto kraće, od 31. prosinca do 4. siječnja, sa spavanjem na istoj lokaciji na Veloj Učki. Zimovanju je prisustvovalo dvadesetak članova, koji su se zabavljali društvenim igrama i upoznavali rad Društva kroz projekcije, a o čemu je osobno izvijestio predsjednik Željko Rubeša:

Mladi i novi članovi izrazili su želju da se upoznaju s radom društva, pa je bilo organizirano upoznavanje članstva s dosadašnjim radom društva, uz razgovor i dijapozitive. Na Staru godinu priređen je ples i kviz natjecanje-poznavanje domovine. Kviz je pripremio Ante Pavlić. No, u toku boravka na Učki priređeno je i nekoliko pješačkih izleta i do Male Učke, vrha Učke i kanjona Vranja. Na tim izletima članovi su upoznali orijentaciju u prirodi. S društvenim kombijem organiziran je posjet do Motovuna i najmanjeg grada na svijetu - Huma. Na kraju zimovanja proglašeni su i najvredniji sudionici zimovanja, a to su ovog puta bili vozač Zoran Rubeša i kuharica Marija Tumpić. (J. Tumpić 1987a)

I te se godine zimovanje pokazuje, bez obzira na nešto kraći period boravka na Učki, kao izuzetno kvalitetan i sadržajan oblik dječjega aktivnog odmora. Uz brojne pješačke ture, mnoštvo je edukativnih sadržaja (orijentacija, kviz), članovi su upoznati s radom Društva, što je iznimno važno za promociju planinarstva i motiviranje novoga članstva, a stiglo se organizirati i jednu ekskurziju u Istru. Bez predanosti i entuzijazma članova organizatora to sigurno ne bi bilo moguće.

Nastavlja se s organizacijom izleta, pa tako članovi organiziraju u prvome vikendu veljače jednu više izletničku ekskurziju na Sviščake, kraj Ilirske Bistrice (šetnja oko skijaških terena) i dalje u razgledavanje Kopra, Buja, Podgrada i Pazina (I. Tumpić 1987).

Iz najave u medijima saznajemo i da se dalje organizira akcija „Žene na Lisinu“, pri čemu je plan da sudionici 7. ožujka autobusom iz Opatije dođu do planinarskog doma na Lisini, naprave planinarsku turu do Brezovice i Mamićevog dolca (gdje je 1944. održana Prva omladinska konferencija kotara Opatija) i eventualno još uspon na Crni vrh. Po povratku do doma zamišljen je topli obrok za sudionike pohoda uz razgovor sa sudionikom NOB-a (Rubeša 1987a). O pohodu izvršenu u potpunosti po planu saznajemo iz sačuvanog izvješća (J. Tumpić 1987b).

Vodiči Društva ponovno su bili angažirani na pohodu „Vrata - Učka ' 87 “, gdje su organizacijski dio najviše preuzeli Željko Rubeša i Ante Pavlić. Više od 200 sudionika došlo je iz Ičića preko Poljana do Tunela Učka, a potom su vodiči 
odlučili nešto izmijenjenom trasom, zbog nabujala potoka Banine ${ }^{19}$, dovesti grupu do odredišta kod Inina odmarališta. Autor članka izvještava da ,[p]o uspješno obavljenom zadatku, planinari su 'za svoju dušu' krenuli preko Poklona - bolnice - izviđačke kućice do Grnjača i Knezgrada pa u Tuliševicu i preko Lovrana vratili se u Opatiju. Tako su još jedno lijepo popodne proveli na padinama Učke, gdje su još neka mjesta prekrivena snijegom.“ (Rubeša 1987b)

Nažalost, prethodno spomenuti apeli Marijana Rubeše na potrebu da se poštuje rad i trud markacista koji uređuju staze i postavljaju planinarsku infrastrukturu itekako dobiva veći smisao i dublje značenje kad imamo na umu i negativne pojave koje su se događale. Tako saznajemo da je Društvo zaprimilo dojavu Marice Juretić, članice Planinarskoga društva „Opatija“, da je razbijen metalni tuljac na Orljaku i da je upisna knjiga nestala. Ogorčen, tajnik piše kako su članovi odmah izašli na teren i zatekli posljedice vandalizma: „Razbacani ubrusi, vrećice od sokova, nered i nečistoća ne služe na čast onima koji su u siječnju posjetili Orljak i udarcima nekog metalnog predmeta uništili vrh tuljca, a cilindar bacili nedaleko. Sreća je da posjetioci nisu iskalili bijes ili obijest na metalnom pečatu [...]. Ovakav vandalizam na Orljaku nije zabilježen. Nadamo se da ga više neće biti!“ (Rubeša 1987c)

Društvo je već tradicionalno uključeno u prvomajske svečanosti na Orlja$\mathrm{ku}$, a u inspiriranom članku tajnika i pokretača te aktivnosti iz 1987. najbolje se dočarava klima koja je vladala tijekom takvih okupljanja. Tako čitamo da su, nakon što su članovi Društva 30. travnja obavili posljednje pripreme i preko Vedeža (zaselak kraj Veprinca) došli na Orljak, prenesli svu opremu i pripremili logor, krenule pripreme za paljenje krijesa i podizanje zastave:

U sakupljanju granja i drva za krijes pridružili su im se i omladinci i pioniri Matulja, Bregi i Rukavca.

Od hrpe granja formiran je krijes. Čeka se 21 sat. Krijes se pali i postavlja proleterska zastava.

Planinari, omladinci i pioniri sakupljaju se oko krijesa. Pjesma se polako i spontano razliježe padinama Orljaka uz zvukove harmonike omladinaca iz Rukavca. Krijes gori do kasno u noć. Sudionici se jedan po jedan neprimjetno povlače u šatore.

Drugi dan, sunčan. Praznik rada. Obavljaju se posljednje pripreme za doček gostiju, koji će prisustvovati proslavi na Orljaku. Stižu Opatijci, Matujci, Rukavčani, Brežani, Veprinčani, Riječani, okupljaju se borci, planinari, izviđači, radni ljudi i građani, omladina i pioniri.

Stiže i planinarska družina „Ključ“ koja nakon proslave na Orljaku i Zadušćini kreće na dvodnevni izlet s noćenjem u lovačkoj kući „Brdo“na Brdu, dok planinari planinarskog društva „Orljak“ ostaju u logorištu do 3. svibnja.

Slijede dani ispunjeni igrom i zabavom, obavljaju se pripreme za predstojeće akcije tijekom ljeta.

19 U članku stoji pogrešno ime potoka - Ričina. 
Uoči povratka spušta se i proleterska zastava. Oprema se odnosi do Vedeža. Još jedan pogled na pusto logorište, rastanak i obećanje: „Opet ćemo na Orljak!"“ (Rubeša 1987d)

Te su riječi nabijene emotivnošću pokretača aktivnosti koji je spomenuta događanja uspio pretvoriti u tradiciju, koju su različite generacije voljele i vraćale joj se. Sjećanje na krijes i ta događanja sveprisutno je u planinarskoj zajednici srednje i starije generacije ljudi s Liburnije i Opatijskog krasa. Ta je aktivnost definitivno postala i ostala centralno događanje Društva, mjesto sabiranja dojmova, planiranja novih akcija, življenja osnovnih postavki i proklamiranih ciljeva koje su se sabirale u višednevno druženje, napose mladih, u prirodi kao svojevrstan vrhunac planinarske aktivnosti. Orljak je kao brijeg pogotovo za članove Društva nosio neko očigledno posebno značenje i postao u punom smislu identitetska odrednica Društva.

Društvo nastavlja s organizacijom pohoda „Stazama NOB-a“, koji je 1987. ostvaren na ruti Bregi - Orljak - Rukavac (Rubeša 1987e) pod vodstvom Željka Rubeše iz Društva te Mirjam Vidas iz Planinarske družine „Ključ““ (J. Tumpić 1987c), a organiziran je i Četvrti marš „Partizanskim stazama“, koji je ove godine organiziran na ruti Vedež - vrh Beljač - Brezovica - Mamićev dolac - dom na Lisini (Rubeša 1987f). Marš je počelo tek desetak sudionika zbog različitih okolnosti, između ostaloga nepojavljivanja najavljenog izviđačkog odreda „Branko Blečićc Lovran, kao i činjenice da se dvadesetak planinara Planinarske družine „Ključ“‘ uspjelo poduhvatiti ovog marša tek dvadesetak dana kasnije i time odati priznanje pohodu (Rubeša 1987g).

Posljednjih dana kolovoza održan je izlet u Sloveniju, na kojemu su pretežno bili mladi. Planinari su razgledali prirodu Idrijskoga gozda, prespavali prvu noć u Planinarskom domu „Rudar“ u Vojskom, zatim razgledali partizansku bolnicu „Franja“ te krenuli uz obalu Soče u pravcu Tolmina, gdje su razgledali grad. Razgledali su slap Boka, zaustavili se u Bovcu te prespavali u planinarskom domu u Lepeni. Treći dan bili su na izvoru Soče. gdje su neki prvi put hodali uz pomoć klinova i sajli te uz obavezno zaustavljanje kod spomenika Juliusu Kugyu, šetnju uz Tičarjev i Poštarski dom na prijevoju Vršiču te razgledavanje spomenika ruskim zarobljenicima, nastavili u Kranjsku Goru. Posebno se ističe da je vedro raspoloženje održavao vozač Valero Benčić - Vale (J. Tumpić 1987d), legendaran, iznimno šaljiv vozač autobusa, dobro poznat starijim generacijama liburnijskoga kraja, koji je često prevozio planinare Društva i uveseljavao ih (Trinajstić 2021).

Društvo sudjeluje 29. rujna 1987. na izletu na Zagradski vrh iznad Bribira povodom 20. obljetnice Riječke planinarske transverzale, pri čemu se posebno ističe grupa transverzalaca, od kojih su već neki završili obilaznicu i drugi put su na transverzali, a neki su je tim pohodom upravo završili (Rubeša 1987h).

Izlet u Borovnicu organiziran je pak 7. studenog, gdje je glavni cilj bio kanjon Pekel rijeke Borovnišnice. Petnaestak se članova tako uputilo vlakom u Sloveniju i prošlo kanjon, pri čemu su se neki prvi put susreli s klinovima i 
sajlama. Kako je vlak kasnio u Matulje, planinari nisu uspjeli uhvatiti autobus za Opatiju pa su otišli, zaboravljajući na umor uz smijeh i šalu - pješke (Rubeša 1987i).

Grupa transverzalaca za praznike uz Dan Republike poduzima obilazak prvih točaka Slovenske planinske poti te uspješno obilaze kontrolne točke Ankaran, Tinjan i Sočerb i uspinju se na Slavnik. Nažalost, zbog lošega vremena odustaju od uspona na Nanos i umjesto toga kreću u Grad Snežnik, no ostaju razočarani zatvorenim svratištem i dvorcem te se zbog silnog snijega otežano polako vraćaju kući (Rubeša 1987j). No u prosincu već nadoknađuju propušteni Nanos i obilaze Vojkovu koču na toj planini te pješače do Furlanova zavetišča pri Abramu i posjećuju Škocjanske jame, koje su zatvorene, ali ipak dobivaju ovjeru kontrolne točke Slovenske poti (Rubeša 1988a).

Članovi Društva u novoj godini sudjeluju ponovno na 26. memorijalu „26 smrznutih partizana“" (Tumpić 1988a), polazeći toga puta iz Begova razdoblja po debelom snijegu, što su najviše iskoristili mlađi za igranje i zabavu (J. Tumpić 1988b).

Ponovno je organizirana akcija „Žene na Lisini“" sa sličnim planom kao i prethodne godine: glavnom bazom i toplim obrokom u planinarskom domu „Stanko Jurdana“ u Lisini (Rubeša 1988b). Međutim iako je odaziv na pohod 5. ožujka 1988. omela kiša, a u Lisini čak i snijeg te se pojavilo mnogo manje od broja prijavljenih, a osim toga i planirani uspon na Vodičku grižu ostao je neostvaren, ipak su se sudionici zabavili u domu, toga puta i u društvu harmonikaša. Istaknuto je da je najstarija članica pohoda bila Marica Juretić (Planinarsko društvo „Opatija“), a najmlađa Kristina Popeškić (Osnovna škola „Viktor Car Emin“ Lovran) te da je Ludmila Vavra bila sudionica na sva tri pohoda (Rubeša 1988c).

Redovna skupština Društva održana je 24. siječnja 1988., a u opsežnu novinskom izvješću saznajemo o tijeku skupštine, između ostaloga o stanju članstva i glavnim akcijama koje su snažno međusobno povezane: ,, [...] društvo broji stotinjak članova, od kojih su dvije trećine mladih, pionira i omladine, a onu treću trećinu čine iskusni planinari i borci, pa je sasvim razumljivo da u ovom društvu prevladavaju dvije vrste aktivnosti kojima se poklanja posebna pažnja. Prvo je okupljanje mladih, a drugo njegovanje revolucionarnih tradicija.“ (Miletić 1988a) Doznajemo da je rasprava bila opsežna, iako su sami članovi najmanje govorili, a istaknuli su se Baldo Stanta uime Planinarskoga društva „Opatija“ i Vilim Radetić uime Saveza izviđača Opatija, kada su obojica govorili o ogromnim problemima s kojima se suočavaju planinarstvo i izviđaštvo, pri čemu su u prvome planu izostanak financijske potpore i izostanak mlađih kadrova koji bi preuzeli vodstvo, stoga se ti oblici rekreacije nalaze u ozbiljnoj krizi (Miletić 1988a).

Ponovno su članovi Društva bili vodiči velikoj grupi - ukupno 185 sudionika - na 25. jubilarnom maršu „Vrata - Učka '88“, no zbog priličnog zakašnjenja sudionika autobus je sudionike odveo do Tunela Učka, odakle se kratilo za Inino 
odmaralište. Nakon same svečanosti planinari su posjetili „mjesto pogibije Antona Mihića, te preko Dobreća i Opriča stigli do Ike.“ (Rubeša 1988d)

Zanimljivo je da je Društvo organiziralo i višestruko prikazivanje jednoga planinarskog filma. Društvo je tako unajmilo od Planinarskog saveza Hrvatske film Čovjek i planina, posvećen 110. obljetnici planinarstva u Hrvatskoj, te u suradnji s Odredom izviđača „Opatija“ dogovorio prikazivanje. U članku se navodi da je film prikazan u Osnovnoj školi „Edvard Kardelj“ u Matuljima pred 150 učenika, da je prikazivan u izviđačkom stanu u Opatiji pred oko 200 ljudi i najavljeno je njegovo prikazivanje u osnovnim školama „Ljubomir Mrakovčić“ u Opatiji i „Viktor Car Emin“ u Lovranu. Prikazivanjem je rukovodio starješina opatijskih izviđača Nikola Turina (Rubeša 1988e).

Snažnija suradnja sa školama, zacrtana još na redovnoj skupštini (Miletić 1988a), nastavljena je još jednom aktivnošću. Društvo je za 30 učenika Područne osnovne škole „Eugen Kumičić“ iz Mošćeničke Drage, Osnovne škole „Ljubomir Mrakovčićc“ iz Opatije i Područne osnovne škole „Narodnog ustanka“ iz Rukavca organiziralo posjet i polaganje cvijeća na spomen-obilježja NOB-a u Veprinačkoj šumi (Trinajstić 1988).

Društvo je tradicionalno održalo i prvomajski logor na Orljaku, od 29. travnja do 3. svibnja uz klasični protokol: nošenje opreme od Vedeža, postavljanje šatora (logora), podizanje logorske zastave ${ }^{20}$, pripremljena i zapaljena logorska vatra, čišćenje vrha od otpadaka, priprema i paljenje krijesa, zabava uz vatru. $\mathrm{Na}$ sam praznik slijedi ukrašavanje vrha za proslavu, dočekivanje gostiju i sudjelovanje u prigodnom programu. Tmurno vrijeme i kiša poremetili su planove za kraće izlete pa se pretežno sve svodi na zabavu u logoru i jelo pod šatorima, nakon čega je slijedilo raspremanje logora i nošenje opreme natrag u Vedež (Rubeša 1988f).

U proslavi 27. srpnja 1988., povodom Dana ustanka naroda SR Hrvatske, sudjeluju i planinari. Društvo organizira ponovno marš „Partizanskim stazama“, a Planinarsko društvo „Opatija“ partizanski ručak (Miletić 1988b). Taj je marš Društva bio jubilarni, peti, a trasa je vodila „od Poklona do Prihvatne sanitetske stanice na Lovranskim sjenokošama i od tuda do Odmarališta INA na Učki, gdje je bila centralna proslava Dana ustanka“, koju je prošlo tridesetak sudionika predvođenih Vilimom Radetićem kao vodičem te informiranih o podacima iz NOB-a ovog kraja, o čemu je na temelju svojih sjećanja govorio Baldo Stanta na lokalitetu Prihvatne sanitetske stanice. Priložena je i fotografija Marija Rubeše s marša (Rubeša 1988g).

Ponovljen je opet krajem kolovoza izlet u kanjon Borovnišnice te su se neki čak i okupali u jezeru, a pojavila se ideja da se barem jednom godišnje odlazi svake godine na ovaj izlet (Tumpić 1988c).

20 Vrlo zanimljiv navod koji govori u prilog jednoj svjetonazorskoj sprezi planinara Društva i izviđača. 
Ono što definitivno među svim izletima Društva ostavlja najveći dojam u smislu planinarskoga pothvata svakako je organizirani šestodnevni uspon na Triglav u kolovozu te godine. Prvi dan stiglo se autobusom do Bohinjskog jezera i pješačilo do Vodnikova doma, gdje se spavalo. Drugi dan uspelo se do Doma Planika, no kako se većina od desetak sudionika prvi put suočavala sa sajlama i klinovima, hodalo se nešto opreznije. Treći dan zbog vjetra i magle uspon na Triglav nije bio moguć, pa je iskorišten dan za predah, ali već popodne vrijeme se poboljšava i petorica planinara uspijevaju se popeti na Triglav. Četvrti je dan slijedilo spuštanje od Doma Planike do Doline Triglavskih jezera, a usput su posjetili domove na Doliču i Prehodavcima te nastavili do Doma pod Bogatinom, gdje je bilo noćenje. Posljednji dan spustili su se preko Doma na Komni do Koče pri Savici, gdje su posjetili i slap Savice te nastavili autobusom prema Opatiji. Priložena je i fotografija stolića sa žigom Marija Rubeše na vrhu Triglava (Tumpić 1988d).

\subsection{Nove promjene u vodstvu Društva i nastavak zacrtanoga rada (1989.-1991.)}

Izborna skupština Društva održana je 5. veljače 1989. u prostorijama Odreda izviđača Opatija, a uz izbor potrebnih tijela i potrebnih izvještaja (financijski, o radu) na dnevnome redu te skupštine bili su i prijedlog i rasprava o programu rada za 1989. godinu, podjela priznanja za peti marš „Partizanskim stazama“ te podjela priznanja organizacijama, društvima i pojedincima (HPS Izvršni odbor 1989). Nema drugih podataka o toj skupštini.

U jednoj vijesti iz dvobroja Naših planina za svibanj-lipanj saznajemo da su istarska društva osnovala „koordinacijski planinarski odbor u kojem sudjeluju iz Hrvatske 'Glas Istre' Pula, 'Planik' Umag, 'Pazinka' Pazin i 'Orljak' Opatija te iz Slovenije Obalno PD 'Tomos' iz Kopra, SPD Trst, PD 'Sežana' i 'Snežnik' Ilirska Bistrica. Sastali su se 12. veljače pod Brajkovim vrhom gdje Glas Istre gradi kuću. Dogovorili su se o usklađivanju markacija, jer neka društva izvan ove regije samovoljno markiraju po Istri.“ (Uredništvo 1989) Ta vijest važna je iz nekoliko razloga. Prvo, Društvo se uključuje u veće koordinacijske odbore, a drugo, ono je s područja Opatije upravo u markacističkom odboru, što dijelom govori u prilog snazi Društva po pitanjima markiranja i održavanja staza.

O visokoj razini organizacije samih aktivnosti, poput svečanosti „Zastava na Orljaku“, svjedoče sačuvani materijali u arhivi Hrvatskoga planinarskog saveza. Naime u travnju 1990. Društvo šalje poziv u Hrvatski planinarski savez s brojnim materijalima. Osim samoga teksta poziva ,na marš 30. travnja od Kućeli do Orljaka i na proslavu 1. svibnja 1990. na vrhu Orljaka gdje će se uoči Prvog maja podići Proleterska zastava" (HPS Organizacioni odbor proslave 1990a) poslan je detaljan program proslave te kopija generalnoga dopisa koji je poslan drugim društvima i organizacijama s detaljnim uputama kako doći do ishodišta pohoda i koja je sve oprema potrebna. U prilogu se nalazi i prijavnica za pla- 
ninarska društva / društvene organizacije (HPS Organizacioni odbor proslave 1990b, 1990c).

\section{Stagnacija rada 1990-ih}

Umirovljenje Marija Rubeše u drugoj polovici 1990-ih (Miletić 2021) uzrokovalo je nemogućnost onako tijesne suradnje s vatrogascima kao prije, ali i izostanak određenih logističkih mogućnosti koje su prije spomenute, što je bio snažan logistički udarac za Društvo. Domovinskim ratom zamire planinarska aktivnost i Društvo se bavi humanitarnim radom da bi uz još par zapaženih akcija polako slabila njegova aktivnost.

\subsection{Zamiranje aktivnosti za vrijeme Domovinskoga rata}

Domovinski je rat bio snažan udarac radu svih udruga, pa tako i planinarskim društvima ne samo na liburnijskome području nego generalno. ${ }^{21}$ To se vrlo dobro ogleda u broju članova iz dopisa Hrvatskom planinarskom savezu, u kojemu se potražuje po 15 markica po uzrastu za 1994. godinu, dakle ukupno 45 članskih markica, što je bilo neko očekivanje vodstva, uz napomenu da se vraća 30 (prethodne godine) neprodanih markica uz objašnjenje:

Kako je već svima poznata situacija /besparica i migracija ljudi/, dolazi do osipanja društva. No ipak ona srž koja je stvarala društvo je ostala i nastojat će oživiti aktivnosti tokom 1994. godine, a naročito među mladeži. Interes postoji jedino treba pronaći financijsku potporu, no dosada smo uspijevali pa računamo da ćemo naići na razumijevanje.

Članstvo je i dalje angažirano na radu i pomoći u gradskom Crvenom križu, na zbrinjavanju, podjeli hrane među stanovništvom i pristiglim izbjeglicama i prognanicima. Tu smo se zdušno založili i učinili sve raspoloživo. (HPS Kveder ${ }^{22}$ i Rubeša 1993)

Dakle u jeku Domovinskoga rata (1991.-1995.) Društvo, kao i brojne druge udruge građana, doživlja razdoblje krize. Ono se ogleda u financijskim problemima, kako je vidljivo iz dopisa, ali ponajveći je udarac na članstvo i jezgru koja uopće može biti nositelj aktivnosti. Ipak, osnivači i najaktivnija članska jezgra nastoje upregnuti postojeće snage u onom smjeru koje vide najpotrebnije za tadašnje prilike: humanitarno djelovanje u sklopu Crvenoga križa. Društvo tako sudjeluje u prikupljanju humanitarne pomoći, koja se redovito šalje na ratna područja Gospića i okolice od rujna 1991. do lipnja 1994., zatim sudjeluje kao ekipa, ali i pomaže prilikom natjecanja Crvenoga križa u pružanju prve pomoći (Simičević 1997).

21 Primjerice i u Planinarskome društvu „Opatija“ u tome razdoblju također znatno zamire aktivnost (Eterović i Ružić 2021: 40).

22 Lovorka Kveder potpisana je kao tajnica, no „Orljak“ je u svome izvršnom tijelu imao dva tajnika, a onaj ovlašten za zastupanja gotovo je cijelo postojanje Društva bio Marijan Rubeša. 
O zamiranju aktivnosti saznajemo i iz izvješća priloženog zapisniku sa skupštine 1995. godine, a koji su svi zajedno priloženi Zahtjevu za upis u Registar udruženja građana:

Zbog društvenih i političkih prilika u zemlji, koje su imale utjecaja na rad društvenih organizacija, pa tako i na naše Društvo, ono je od 1991. mirovalo i brojčano se smanjilo, a k tome još uvijek smo bez društvenih prostorija i stalni beskućnici. (UO-OP Zahtjev 1995: Izvještaj o radu u proteklom razdoblju)

Izvješće dakle potvrđuje tešku situaciju u Društvu za vrijeme Domovinskoga rata, ali posebno treba istaknuti nedostatak društvenih prostorija, što je možda i jedna od najtežih okolnosti za normalno funkcioniranje Društva. Zbog toga su odrasli članovi Društva primorani snalaziti se i „dogovore [su] imali na izletima, jer nedostatak prostorija stvara određene teškoće.“(UO-OP Zahtjev 1995: Izvještaj o radu u proteklom razdoblju)

\subsection{Ponovno buđenje aktivnosti (1995.-2000.)}

U spomenutim prilozima s izvanredne skupštine, održane 10. 12. 1995. godine, doznajemo pregršt dragocjenih podataka. Prije svega, saznajemo sam datum skupštine, doznajemo da, uslijed nove legislative, Društvo traži da bude upisano u registar udruženja građana kao sljednik istoimene društvene organizacije, da je predsjednik Društva Zoran Rubeša, ${ }^{23}$ da su osobe ovlaštene za zastupanje tajnik Mario Rubeša i dopredsjednik Claudio Primc, da je donesen novi statut uslijed zakonskih promjena te saznajemo koji je sastav Izvršnoga odbora: Zoran Rubeša, Claudio Primc, Željko Rubeša i Mario Rubeša (UO-OP Zahtjev 1995). U oko upada znatno smanjenje broja članova izvršnog tijela Društva, čemu se očito moralo pribjeći s obzirom na izuzetno malen broj (aktivnih) članova. Zahtjev sa svim prilozima predan je 20. 12. nadležnoj ustanovi, a Društvo je upisano u novi Registar udruženja građana nekoliko dana kasnije - 27. 12. 1995. (UO-OP Rješenje 1995). Najavljeno je i ozbiljno bavljenje rješavanjem pitanja prostora (UO-OP Zahtjev 1995: Izvještaj o radu u proteklom razdoblju), što će se sljedeće godine i pokušati zakupom prostora u podrumskoj prostoriji na adresi Ulica maršala Tita 113, Opatija (UO-OP Zahtjev 1996), koja je i odobrena kao nova adresa Društva (UO-OP Rješenje 1996).

Nekoliko riječi treba reći o novome Statutu Društva, usklađenu s novom legislativom o udrugama. Zanemarujući opće formalno nužne odrednice, pozornost treba svrnuti barem na dvije stvari. Prvi se put spominje znak Društva, iako on funkcionira i ranije (žigovi, naljepnice, prigodne posjetnice):

Znak društva je kontura planine sa znakom markacije na desnoj trećini konture planine, u podnožju su obrisi morske obale sa palmama i na moru

23 S obzirom na to da, kako je spomenuto, nema više sačuvanih podataka o izbornoj skupštini 1989. godine, ne možemo reći kad je točno Zoran Rubeša postao predsjednik, a sjećanja govornika nisu pružila taj podatak. Sigurno je samo to da Zoran Rubeša 1995. obnaša tu funkciju i, kako ćemo vidjeti, na njoj ostaje do kraja postojanja Društva. 
dvije jedrilice. Iznad kontura planine je tekst Planinarsko društvo „ORLJAK“ Opatija. (UO-OP Statut 1995: 1)

Druga je pak važna stvar ta da među ciljevima više ne nalazimo onu usku povezanost s vatrogascima i zaštitom od požara, već su navedeni opći planinarski ciljevi, zadaci i djelatnosti (UO-OP Statut 1995: 1-2).

Također saznajemo da je pokrenut i niz aktivnosti s ciljem ponovnog oživljavanja Društva u toj godini:

Ove 1995. počelo se većom aktivnošću, pa se i omasovilo. Učlanilo se novih 30 učenika Osnovne škole Opatija i pet odraslih, pa sa 23 stara člana Društvo čini ukupno 58 članova, no to nije ni izdaleka koliko je Društvo nekad brojilo.

Aktivnosti su se povećale osobito na terenu opatijske rivijere, a naglasak je naročito dat ekologiji. Organiziran je Skup planinara ljubitelja prirode „Učka '95“ od 22. do 24. rujna ove godine u Hotelu INA na Učki pod motom „Očuvajmo šume Učke i Lisine“. (UO-OP Zahtjev 1995: Izvještaj o radu u proteklom razdoblju)

Da je ekologija još i snažnije postala trajno obilježje rada Društva, saznajemo iz niza izvješća o radu Društva. Tako primjerice ostaje sačuvan zapis da je 1995. Društvo suorganizator skupa planinara i ljubitelja prirode „Učka '95“, a da akciju koordinira ,lokalni povjerenik eko-patrola za Istru i Kvarner Mario Rubeša iz Opatije“" (Starčević 1995). Već sljedeće godine Društvo reagira dopisom Komisiji za zaštitu prirode Hrvatskoga planinarskog saveza po pitanju sječe stabala na Sisolu (Starčević 1996), a te iste godine suorganizator je skupa „Učka '96“, dok s omladinskom sekcijom Hrvatskoga planinarskog društva „Zagreb-Matica“" priređuje dvodnevni izlet 21. i 22. rujna 1996. pod nazivom „Liburnijski vrhovi Učke“" te unatoč nezapamćenoj kiši pod vodstvom Balda Stante i Željka Rubeše realizira izlet (M. T. 1996).

Iz istog priloga sa spomenute skupštine saznajemo da se intenzivno radi i na obnavljanju staza:

U ljetnim mjesecima prišlo se obnovi - markiranju planinarske staze Jušići - Lisina - Vodice. Tu su se naročito odazvali mlađi članovi, dok su stariji bili voditelji. Naoko ovo je mala akcija, ali ako računamo da su staze bile zapuštene i slabo markirane onda je to popriličan rad. (UO-OP Zahtjev 1995: Izvještaj o radu u proteklom razdoblju)

Kada pak govorimo o markacističkoj djelatnosti Društva, koja se ponovno budi, treba reći da se u tome poslu posebno istaknuo Baldo Stanta, ,legenda hrvatskog planinarstva“" (Skorić 1999b), a koji je bio jedan od spomenutih starijih voditelja u poslu obnavljanja puteva te istaknuti društveni radnik i promotor planinarstva. ${ }^{24}$ Pri tome posebno treba istaknuti njegov rad na održavanju staze

24 Stanta je bio dugogodišnji tajnik opatijske osnovne škole, uvijek spreman na podršku aktivnostima koje su se ticale mladih, posebno onih vezanih za boravak u prirodi (Miletić 2021, Trinajstić 2021). Održao je gostujuća predavanja na mnogim događanjima, primjerice svojim je predavanjem na skupu Šetališta u opatijskoj lječilišno-turističkoj ponudi „opisao [...] 
Mala Učka - Plomin preko grebena Sisola najčešće uz pomoć supruge Marije, s kojom se 1995. godine uključuje u rad Društva (prešli iz Planinarskoga društva „Opatija“) i kada oboje stječu naziv markacista (HPS KP Rubeša 2000h, 2000i). ${ }^{25}$ Baldo Stanta bio je i nositelj ciklusa predavanja koja je držao za javnost uime Društva.

Izrazita okrenutost ekologiji i zaštiti prirode bila je usko vezana uz rad s mladima i njihovu edukaciju. Društvo je tako od 1995. do 1997. organiziralo tri okrugla stola na temu zaštite prirode (Simičević 1997), a u 1995. kreće ponovno $\mathrm{u}$ intenzivniji rad s mladima, koji se uključuju u sve aktivnosti tek uz pomoć odraslih:

Održano je 30 tjednih sastanaka sa školskom djecom, 9 izleta, jedan bivak i 4 radne akcije markiranja. U svim tim aktivnostima sudjelovali su i seniori Društva. (UO-OP Zahtjev 1995: Izvještaj o radu u proteklom razdoblju)

Rad s mladima i zaštita prirode tako postaju okosnice u radu Društva. Da je to ponovno oživjelo aktivnost Društva, dokazuje članak o predstavljanju planinarstva u Opatiji, u kojemu je prikazan i rad Društva. U njemu saznajemo da Društvo početkom $1997 .{ }^{26}$ broji 127 članova, s pretežno mlađim članstvom: 2 predškolca, 15 srednjoškolaca i 10 studenata (Simičević 1997), što je značajno omasovljenje članstva.

Treba reći da je 13. 12. 1997. održana izvanredna skupština na kojoj je izglasan sitno dopunjen i izmijenjen Statut radi usklađivanja s novom legislativom (primjerak statuta nije sačuvan) te je 5.1. 1998. Zahtjev sa svim prilozima predan nadležnoj ustanovi (UO-OP Prijava 1998: Zapisnik). Iz priloženog izvješća o radu u 1997. godini saznajemo niz važnih podataka: da je broj članova 112 (od čega 66 mladih), da se aktivnosti s mladima redovito odvijaju u opatijskoj osnovnoj školi, da markacisti rade na održavanju putova, pri čemu se posebno ističe bračni par Baldo i Marija Stanta, da grupa ekologa aktivno radi na što bržem proglašenju Učke parkom prirode, da je 8 članova društva na odgovarajućem seminaru Hrvatskoga planinarskog saveza steklo zvanje čuvara prirode (voditelj seminara bio je Mario Rubeša), da je Mario Rubeša imenovan od strane Komisije za zaštitu prirode Hrvatskoga planinarskog saveza početkom 1996. povjerenikom za zaštitu Učke i Ćićarije te da je Društvo u suorganizaciji s Planinarskim društvom „Skitaci“27 iz Labina organiziralo okrugli stol Izgradnja jadranskih termoelektrana i njihov utjecaj na okoliš u Hotelu „Marina“ u Mošćeničkoj Dragi (UO-OP Prijava 1998: Izvještaj).

važnost Učke i njenog položaja koji omogućava Opatiji biti turistička i medicinski interesantna destinacija." (Skorić 1999b)

25 O djelovanju Balda i Marije Stanta u okviru Planinarskoga društva „Opatija“v. više u Eterović i Ružić 2021: 35-40, 126-129.

26 Brojke se vjerojatno odnose na stanje u 1996. godini.

27 U izvoru stoji pogrešno Skitanci. 
Društvo, predvođeno svojim tajnikom, i dalje organizira brojne stručne skupove i okrugle stolove na temu zaštite prirode, poput primjerice predstavljanja Zeleno-plave opcije 1999. godine (Skorić 1999a).

O tome predstavljanju te nekim drugim akcijama i aktivnostima Društva saznajemo opet više iz nacionalnoga planinarskoga glasila, nakon više godina tišine o Društvu. Tako se izvještava da je 27. veljače 1999. Vesna Jurković iz Šibenika, članica Komisije za zaštitu prirode Hrvatskoga planinarskog saveza, održala predavanje. Autorica ne propušta izvijestiti i o drugim aktivnostima organizatora toga skupa te navodi da je za 15 . obljetnicu Društva pokrenut niz akcija kao što su:

- Zaštite Učke i njenog proglašavanja Park šumom, odnosno parkom prirode[.]

- Naš je član imenovan za povjerenika Komisije za zaštitu prirode za Učku i Ćićariju, a posebna se briga vodi o pisanoj i fotodokumentaciji koja govori o ekološkom uništavanju Učke.

- Pomladak od 45 članova „Rikard Katalinić Jeretov“ u Opatiji, njihov se rad u školi registrira kao slobodna aktivnost.

- Društvo ima i ekipu markacista koja markira planinarske staze u koju ćemo ovog ljeta uključiti i nekoliko mladih planinara, a kako se Opatija okreće zdravstvenom turizmu, to mislimo da bismo i tu mogli pomoći jer su staze na Učki i okolnih vrhova vrlo atraktivne i zdravstveno poželjne. (Miletić 1999a)

Iz lipanjskoga broja istoga časopisa doznajemo nešto više o spomenutome aktivu u opatijskoj osnovnoj školi te o susretu sa Stipom Božićem u okviru obilježavanja 15. godišnjice Društva:

Suradnja s Osnovnom školom „Rikard Katalinić Jeretov“ u Opatiji bilježi niz uspješnih rezultata. U planinarski podmladak, koji djeluje već pet godina, učlanjeno je pedesetak učenika, a sekcija se u programu i planu škole tretira kao slobodna aktivnost. Osim redovitih sastanaka, izleta i pohoda, te redovitih izložbi fotografija koje pokazuje učeničku aktivnost u tijeku te godine, ovogodišnji ožujak obilježen je i sadnjom borovih sadnica. Šumarija Matulji poklonila je društvu dvadesetak borovih sadnica, koje su učenici ekolozi pod vodstvom Norme Srbulj, profesorice biologije, zasadili na padinama te pod vrhom Orljaka u masivu Učke. [...]

U programu obilježavanja 15. obljetnice, društvo je organiziralo 17. ožujka susret sa Stipom Božićem, jedinim Hrvatom koji je osvojio vrhove sedam kontinenata. Naziv susreta je bio „Moji usponi na krov svijeta“. (Miletić 1999b)

Iz toga je jasno da je učinjen izuzetan iskorak ponovno u radu s mladima, što je obilježavalo rad Društva od samih početaka.

U istome broju toga časopisa saznajemo da je Učka s još nekim područjima napokon proglašena parkom prirode nakon dugogodišnjega zalaganja, čak od 1995., Komisije za zaštitu prirode i lokalnih planinarskih društava (I. S. 1999). 
U tome je zalaganju po pitanju proglašenja Učke prednjačilo upravo Društvo, pri čemu je enorman angažman u tome bio upravo onaj Maria Rubeše (Miletić 2021).

Osim što je Društvo bilo među najglasnijima u prosvjedima protiv gradnje radara na Učki, ono se snažno zalagalo i posebno bilo aktivno u akcijama za proglašenje Učke parkom prirode od samih početaka (Rubeša 2016). U svim organizacijskim poslovima Društva najaktivniji je od njegovih početaka pa do kraja bio Mario Rubeša, ali posebno treba istaknuti njegov angažman na području zaštite prirode, gdje je bio konzultant na elaboratu za pripremu proglašenja Učke parkom prirode (Rubeša 2016; Miletić 2021).

Rubeša je zbog svega toga od strane Komisije za zaštitu prirode Hrvatskoga planinarskog saveza imenovan povjerenikom Komisije za Učku i Ćićariju, o čemu je sačuvan dokument potvrde tog imenovanja (TCM Ferina 2000), a na njegov je prijedlog ta Komisija 2001. odobrila osnivanje Povjerenstva za Učku i Ćićariju u sastavu Mario Rubeša, Lidija Runko-Luttenberger i Tomislav Miletić (TCM Ferina 2001). Pritom je sam Rubeša postavljen za predsjednika Povjerenstva uz detaljno obrazloženje odluke:

Predsjednik povjerenstva, prvoimenovani Mario Rubeša, osim neumornog rada u proglašenju i sada u gospodarenju PP „Učka“, u svojim djelatnostima godinama provodi široke akcije edukacije u zaštiti prirode podstičići [!] osim planinara i djecu osmoškolskog uzrasta, kao i njihove nastavnike - odgajatelje. Osim svega navedenoga, u posljednje vrijeme porast obima poslova povezan uz akciju „NE RADARIMA NA UČKU“ traži povećanje broja suradnika. Želim napomenuti da je 2002. godina proglašena za godinu zaštite planina (pod motom „Planine su ugrožene“) i godinu Održivog turizma - čime se i opet treba baviti osnovano povjerenstvo kroz aktivnosti zaštite planinske prirode i Zeleno-plavu opciju povezivanja turizma i planinarstva na održivi način. (TCM Ferina 2001)

Pored obuke članova (npr. za markaciste, za čuvare planinske prirode), koja je bila dobrovoljna i nefinancirana od Društva, te edukacije širega građanstva kroz predavanja i okrugle stolove, Društvo je provodilo brojne aktivnosti u kojima je promoviralo Liburnijsku rivijeru, Opatiju i ljepote Učke. Tu se može spomenuti održavanje nekoliko godina zaredom redovite akcije »Pješačenjem do zdravlja « pod motom »Korak na korak « u povodu Dana Grada Opatije, zatim slične akcije u povodu Svjetskog dana čistih planina te u povodu Memorijala Andrije Petriča (Rubeša 2016).

\section{Postupna stagnacija i prestanak rada 2000-ih}

Ulaskom u novo tisućljeće sve je manje zabilježenih vijesti o Društvu. Starenjem i slabljenjem energije Maria Rubeše Planinarsko društvo „Orljak“ polako gubi na snazi i njegova aktivnost u potpunosti zamire uz tek nekoliko zapaženijih aktivnosti. 
Treba posebno istaknuti i pohvaliti inicijativu vodstva Društva da se nagrade najaktivniji i najzaslužniji članovi. Dana 9. veljače 2000. pripremljen je i poslan Hrvatskom planinarskom savezu popis predloženika za priznanja uz obrazloženja koji je sačuvan u fondu Komisije za priznanja Hrvatskoga planinarskog saveza (HPS KS). Dodjela je tih priznanja i simboličko zaokruženje najaktivnijega razdoblja djelovanja Društva.

Za zlatni je znak tako predložen Baldo Stanta s obrazloženjem o izuzetno bogatoj aktivnosti. Saznajemo tako da Stanta planinari od 1938., posebno aktivno od 1960-ih u Planinarskom društvu „Opatija“, u kojemu se od 1972. aktivno bavi markiranjem putova. Godine 1973. osniva planinarsku sekciju u opatijskoj osnovnoj školi, s kojom radi do odlaska u mirovinu 1979. Između 1988. i 1990. održava niz predavanja s dijapozitivima po opatijskim, matuljskim i riječkim školama, a u ožujku 1995. uključuje se u rad Društva, gdje nastavlja posebno s aktivnošću markiranja (markirao grebensku planinarsku turu od Učke do Plomina). Završio je niz transverzala i dobio brojna planinarska priznanja i diplome. Bio je suradnikom u vodiču Planine Hrvatske Željka Poljaka te aktivist Crvenog križa (HPS KP Rubeša 2000h).

Za srebrni je pak znak predložen Mario Rubeša s opsežnim obrazloženjem. Planinari od 1952., 1980. osniva Planinarski aktiv „Orljak“, a 1984. potiče njegovo osamostaljenje u zasebno planinarsko društvo, kojemu postaje tajnik, bivajući na toj funkciji i u trenutku predlaganja za priznanje. Nakon umirovljenja 1987. još se aktivnije posvećuje planinarstvu i radu s mladima u opatijskoj osnovnoj školi. Neko vrijeme bavio se transverzalstvom i obišao desetak transverzala Hrvatske i Slovenije. Aktivno se uključuje u rad Komisije za zaštitu prirode Hrvatskoga planinarskog saveza, postaje povjerenik za Učku i Ćićariju te izuzetno aktivno radi s grupom ekologa u opatijskoj osnovnoj školi. Do 2000. vodio je oko 250 izleta i pohoda po Hrvatskoj i Sloveniji. Registrirani je markacist od 27. 11. 1993. Organizator je brojnih pohoda, marševa, bivaka, 4 okrugla stola i desetak društvenih izložbi (HPS KP Rubeša 2000e).

Za brončani je znak predložen niz istaknutih članova. Jadranka Cvek Tumpić bila je članica od osnivanja Društva i aktivna sudionica gotovo svih njegovih aktivnosti, čak i članicom izvršnih tijela Društva. Cijelu je svoju obitelj uključila u planinarstvo i rad Društva, vodila niz akcija i pohoda, bila voditeljica natjecateljske ekipe u pružanju Prve pomoći s izvrsnim rezultatima, sudjelovala je u orijentacijskim natjecanjima te u traganjima i spašavanjima ljudi na Učki i Ćićariji (HPS KP Rubeša 2000b). Mirna Cerin vodila je Društvo u nizu akcija i pohoda, sudjelovala kao natjecateljica u natjecanjima iz pružanja Prve pomoći te u akcijama traženja izgubljenih ili zalutalih osoba. Aktivno je radila na zbrinjavanju prognanika, na dostavi humanitarne pomoći te je sudjelovala u svim akcijama „Šetnja do zdravlja“, koja se odvija u suradnji s Gradom Opatija (HPS KP Rubeša 2000a). Cvjetana Miletić došla je u Društvo kao pravi simpatizer planinarstva te se zalagala za promociju planinarstva među građanima i učenicima. Kao urednica Opatijske komune drastično je pripomogla omasovljenju Društva i njegovoj 
medijskoj promidžbi. Bila je sudionica i pomoćnica u donošenju svih pravnih akata Društva tijekom svojega dvanaestogodišnjeg rada u Društvu, suradnica u edukaciji mladih i cjelokupnoga planinarskog kadra te sudionica svih suvremenih akcija Društva oko promocije zdravlja i zdravoga života (HPS KP Rubeša 2000c). Ivica Rubeša počeo se baviti planinarstvom i orijentacionizmom 1980. u Planinarskome društvu „Opatija“, 1984. aktivno sudjelovao u osnivanju Društva te vodio brojne pohode i izlete. Bio je suorganizator i provoditelj brojnih pohoda, marševa i obilježavanja važnih datuma. Sudjelovao je u potragama za nestalima, u Domovinskome ratu, u zbrinjavanju izbjeglica, u pošumljavanju padina Planika te brojnim natjecanjima u pružanju Prve pomoći. Jedan je od organizatora pohoda „Šetnjom do zdravlja“ (HPS KP Rubeša 2000d). Zoran Rubeša također se počeo baviti planinarstvom i orijentacionizmom 1980. u u Planinarskome društvu „Opatija“, 1984. aktivno sudjelovao u osnivanju Društva te vodio brojne pohode i izlete. U trenutku predlaganja za priznanja bio je predsjednik Društva već u trećem mandatu. Bio je suorganizator i provoditelj brojnih pohoda, marševa i obilježavanja važnih datuma te je sudjelovao u potragama za nestalima, u Domovinskome ratu, u zbrinjavanju izbjeglica i u pošumljavanju padina Planika (HPS KP Rubeša 2000f). Željko Rubeša bio je od 1965. član u Planinarskoga društva „Opatija“, a po osnivanju Društva postaje njegovim članom, u kojemu sudjeluje u trasiranju i markiranju puteva te je registrirani markacist od 27. 11. 1993. Bio je stalni član uprave Društva, suorganizator i provoditelj brojnih pohoda, marševa i obilježavanja važnih datuma te je sudjelovao u potragama za nestalima, u zbrinjavanju izbjeglica i dostavi humanitarne pomoći, pošumljavanju Planika te brojnih natjecanja u pružanju Prve pomoći (HPS KP Rubeša 2000g). Predloženi su i oni članovi koji su možda u manjem obimu, ali kontinuirano doprinosili Društvu. Primjerice za Mariju Stanta u obrazloženju stoji da je stalni suradnik suprugu u svim akcijama vođenja, markiranja i zaštite okoliša te da je aktivna u Društvu od 1995. godine, otkad je i registrirani markacist (HPS KP Rubeša 2000i). Za Dariju Stipanić navodi se da je sudionica mnogih akcija, pohoda i marševa Društva te da nikada nije uzmicala od odgovornijih zaduženja. Sudjelovala je u trasiranju i markiranju Ekostaze Beli na Cresu, na natjecanjima Prve pomoći, u zbrinjavanju prognanika i izbjeglica te u akcijama pošumljavanja Planika i Učke (HPS KP Rubeša 2000j). Sandra Ujčić planinarstvom se bavi od 1980. u u Planinarskome društvu „Opatija“, a 1984. sudjeluje u osnivanju Društva. Vodila je izlete, sudjelovala u organizaciji raznih aktivnosti Društva, na natjecanjima Prve pomoći, u akcijama traženja izgubljenih i zalutalih osoba, u zbrinjavanju prognanika i izbjeglica, u dostavi humanitarne pomoći te u pošumljavanju (HPS KP Rubeša 2000k).

Treba posebno istaknuti da je kao zaseban aktiv formalno u sklopu Društva djelovala i Sekcija „Torpedo“ (dalje: Sekcija). Ona je nastala nakon što je Planinarsko društvo „Torpedo“ iz Rijeke (osnovano 1953.) 2003. godine izmijenilo ime u Planinarskoorijentacijski klub „Torpedo“ te se skupina njegovih članova izdvojila i počela djelovati pod okriljem drugoga planinarskog društva kao posebna sekcija s prepoznatljivim imenom koje je zadržala od matičnoga, prethod- 
no postojećega planinarskog društva. Sekcija je pod vodstvom Borisa Petrića djelovala do samoga gašenja Društva, održavajući društvene izlete, brinući se o održavanju brojnih putova, napose na Ćićariji (koje je ranije održavalo Planinarsko društvo „Torpedo“) te je kao posebnu aktivnost skrbilo o organizaciji redovitoga Memorijala Andrije Petriča (Petrić 2016).

Da Društvo ulazi u određenu krizu s prvim desetljećem novoga milenija, dobro se ogleda u jednome izvješću, gdje je zapisano da početkom 2009. godine ono broji 189 članova, a da je tek tridesetak aktivnih članova. Iz izvješća je vidljivo da je i struktura članstva drastično izmijenjena, s vidnim smanjenjem broja mladih: 2 juniora predškolca, 8 školaraca, 9 srednjoškolaca, 121 senior i 49 umirovljenika. Između ostaloga samo izvješće svjedoči o financijskim te pratećim logističkim problemima s društvenim prostorijama koji su se nagomilali, jer se radi o dokumentu kojemu je predmet zamolba za podmirenje duga, odnosno nagomilanih troškova režija za korištenje društvenih prostorija (TCM Rubeša 2009).

Iz brojnih je dokumenata vidljivo, ali i trajno prisutno u mementu planinarske zajednice Liburnije, da je Mario Rubeša bio udarna igla Društva od samih početaka, najprije kao njegov osnivač, zatim angažiran na svim poljima i aktivnostima Društva te tajnik u cjelokupnome razdoblju postojanja Društva (Miletić 2021). Energija i snaga prisutni u njegovu djelovanju očito nisu bili nadoknadivi jer se Društvo praktički ugasilo smrću svojega osnivača i tajnika 2009., a formalno je izbrisano iz Registra udruga naredne, 2010. godine (Rubeša 2016).

\section{Zaključak}

Planinarsko društvo „Orljak“ iz Opatije tek je jedna od nekoliko stotina planinarskih udruga koje su djelovale tijekom više od sto godina organiziranoga hrvatskog planinarstva (usp. Poljak 1975: 233). Njegov rad još je uvijek vrlo živ u sjećanjima ljudi koji su bili njegovim aktivnim članovima, no u širim je krugovima bio dosad slabo poznat, a nije postojao ni objektivan monografski prikaz njegova djelovanja, što je praznina koju smo nastojali popuniti ovim radom. To je planinarsko društvo tijekom svojega četvrtstoljetnog djelovanja ostavilo jasno vidljiv trag svojega postojanja, $\mathrm{i}$ to ponajprije $\mathrm{u}$ dvama stupovima aktivnosti: rad s djecom i mladima te zaštita prirode.

Zlatno doba djelovanja Planinarskoga društva „Orljak“ odvija se 1980-ih, kada je ujedno aktivnost i snaga Društva na samome vrhuncu. Njegovi članovi sudjeluju u orijentacijskim natjecanjima, oformljena je posebna skupina transverzalaca, uspostavlja se sustavna edukacija djece i mladih, skrbi o markiranju putova na području Učke i Ćićarije, a ujedno osmišljavaju brojni tradicionalni izleti, marševi i pohodi čiji je cilj bio očuvati sjećanje na tekovine Narodnooslobodilačkoga rata. Tijekom Domovinskoga rata Društvo će upasti u krizu od koje se nikada nije uspjelo potpuno oporaviti, no unatoč tomu tijekom 1990-ih nastavlja s aktivnim radom, koji je sada usmjeren ponajprije na aktivnosti zaštite 
prirode, i to u prvome redu na području Učke i Ćićarije (Lisina), što je prepoznato i na nacionalnoj razini, proglašenjem Maria Rubeše povjerenikom za Učku i Ćićariju od strane Komisije za zaštitu prirode Hrvatskoga planinarskog saveza. Premda će se Društvo do kraja prvoga desetljeća novoga milenija ugasiti smrću svojega osnivača i tajnika Maria Rubeše, rezultati su njegova bogata, raznorodna i predana rada ostali vidljivi sve do danas, postavši trajnim naslijeđem ne samo lokalne nego i regionalne i nacionalne planinarske povijesti.

\section{Izvori}

\section{a) Arhivska građa}

1. UO-OP = Arhiva opatijske ispostave Upravnoga odjela za opću upravu i upravljanje imovinom Primorsko-goranske županije.

a. Odluka 1984a. = Planinarski aktiv „Orljak“, Odluka [prijedlog osnivača na masovnom sastanku], Opatija, 1. 3. 1984. [1 stranica].

b. Odluka 1984b. = Planinarsko društvo „Orljak“, Odluka [imenovanje osnivača na osnivačkoj skupštini], Opatija, 19. 3. 1984. [1 stranica].

c. Prijava 1998. = Planinarsko društvo „Orljak“, Prijava radi upisa u Registar udruga Županije primorsko-goranske [Opatija, 5. 1. 1996.; 2 stranice] +5 priloga: Zapisnik izvanredne skupštine [2 stranice]; Poziv na izvanrednu skupštinu [1 stranica]; Popis osnivača udruge [vjerojatno pogrešan obrazac umjesto popisa osoba ovlaštenih za zastupanje, jer su one navedene, 1 stranica]; Izvještaj o radu Društva za razdoblje 22. 12. 1996.-13. 12. 1997. [2 stranice]; preslika osobnih iskaznica osoba ovlaštenih za zastupanje, Marija i Zorana Rubeše [1 stranica].

d. Rješenje 1984. = Socijalistička Republika Hrvatska, Općina Opatija, Općinski sekretarijat za opću upravu i budžet općine Opatija, Rješenje [o upisu u Registar društvenih organizacija općine Opatija], Opatija, 14. 4. 1984. [2 stranice].

e. Rješenje 1986. = Socijalistička Republika Hrvatska, Općina Opatija, Općinski sekretarijat za opću upravu i budžet općine Opatija, Rješenje [o izmjenama u Registru društvenih organizacija općine Opatija], Opatija, 8. 10. 1986. [1 stranica].

f. Rješenje 1995. = Republika Hrvatska, Županija Primorsko-goranska, Ured za opću upravu, Ispostava Opatija, Rješenje [o upisu u Registar udruženja građana Županije Primorsko-goranske, Ispostava Opatija], Opatija, 27. 12. 1995. [2 stranice].

g. Rješenje 1996. = Republika Hrvatska, Županija Primorsko-goranska, Ured za opću upravu, Ispostava Opatija, Rješenje [o izmjenama u Registru udruženja građana Županije Primorsko-goranske, Ispostava Opatija], Opatija, 1. 7. 1996. [2 stranice]. 
h. Statut 1984. = Statut planinarskog društva „Orljak“ Opatija, Opatija, 17. 3. 1984. [20 stranica].

i. Statut 1995. = Statut planinarskog društva „Orljak“ Opatija, Opatija, 10. 12. 1995. [9 stranica].

j. Zahtjev 1984. = Planinarsko društvo „Orljak“, Zahtjev za upis u Registar društvenih organizacija [Opatija, 27. 3. 1984.; 3 stranice] + 3 priloga: Izvještaj [zapisnik] sa skupštine [3 stranice]; Popis osnivača društvene organizacije [2 stranice]; Popis članova organa upravljanja [2 stranice].

k. Zahtjev 1986. = Planinarsko društvo „Orljak“, Zahtjev za upis izmjena $i$ dopuna u Registar društvenih organizacija [Opatija, 2. 6. 1986.; 3 stranice] +2 priloga: Odluka o ovlaštenim osobama za zastupanje; Popis članova organa upravljanja [2 stranice].

1. Zahtjev 1995. = Planinarsko društvo „Orljak“, Zahtjev za upis u Registar udruženja građana [Opatija, 15. 12. 1995.; 2 stranice] + 3 priloga: Kopija Rješenja iz 1984. (UO-OP Rješenje 1984) [2 stranice]; Odluka o osobama ovlaštenim za zastupanje [1 stranica]; Odluka o osnivanju [s napomenom da je udruga pravni sljednik istoimene društvene organizacije, 1 stranica]; Dnevni red izvanredne skupštine [1 stranica]; Zapisnik sa skupštine [2 stranice]; Izvještaj o radu u proteklom razdoblju [1 stranica]; Popis članova kolektivnog izvršnog organa upravljanja [1 stranica].

m. Zahtjev 1996. = Planinarsko društvo „Orljak“, Zahtjev za upis izmjena $i$ dopuna u Registar društvenih organizacija [Opatija, lipanj 1996.; 3 stranice] +1 prilog: Ugovor o zakupu prostora [1 stranica].

2. HPS = Arhiva Hrvatskoga planinarskog saveza - Zagreb, Fond Planinarska društva, Kutija Orahovica - Obruč - Opatija - Orljak, folija Opatija.

a. Balen, Branko. 1981. „Planinarsko društvo 'Opatija'. Izvještaj god. skupštini o radu Upravnog odbora od 1.01.1977.-31.12.1980.“, Opatija, 14. 5. 1981. [13 zaklamanih stranica].

3. HPS = Arhiva Hrvatskoga planinarskog saveza - Zagreb, Fond Planinarska društva, Kutija Orahovica - Obruč - Opatija - Orljak, folija Orljak.

a. Izvršni odbor. 1989. „[Poziv na izbornu skupštinu P.D. 'Orljak']“, Opatija, siječanj 1989. [1 stranica].

b. Kveder, Lovorka i Rubeša, Zoran. 1993. „[Dopis u vezi članskih markica"]", Opatija, 6. 12. 1993., spis 86/93 [1 stranica].

c. Organizacioni odbor proslave. 1990a. „[Poziv na proslavu 'Zastava na Orljaku']“, Opatija, travanj 1990., spis $47 / 90$ [polovica stranice].

d. Organizacioni odbor proslave. 1990b. „[Program proslave 'Zastava na Orljaku']“, Opatija, travanj 1990., spis 48/90 [1 stranica]. 
e. Organizacioni odbor proslave. 1990c. „,Generalni poziv planinarskim društvima i društvenim organizacijama na proslavu 'Zastava na Orljaku'; u privitku upute 'Kako doći u Rukavac' i 'Kako doći na Orljak', uputa 'Oprema učesnika marša' te 'Prijavnica']“, Opatija, travanj 1990., spis $49 / 50^{28}$ [1 stranica +2 i pol stranica privitaka].

f. Rubeša, Marijan. 1983a. „[Dopis Planinarskom savezu Hrvatske u vezi s nabavom transverzala]", Opatija, 11. 3. 1983., spis 14/83 [1 stranica].

g. Rubeša, Marijan. 1983b. „,[Drugi put ponovljeni dopis Planinarskom savezu Hrvatske u vezi s nabavom transverzala]“, Opatija, 27. 6. 1983., spis 64/83-0 [1 stranica].

h. Rubeša, Marijan. 1983c. „[Dopis Planinarskom društvu 'Mosor' u vezi s nabavom transverzale Mosorski planinarski odred]", Opatija, 3. 5. 1983., spis 39/83-T [polovica stranice].

i. Rubeša, Ivica. 1983a. ,[Dopis Planinarskom društvu 'Troglav' u vezi s nabavom transverzale Jubilarnih 25 vrhova] “, Opatija, 30. 3. 1983., spis 25/83-T [polovica stranice].

j. Rubeša, Ivica. 1983b. ,[Ponovljeni dopis Planinarskom društvu 'Troglav' u vezi s nabavom transverzale Jubilarnih 25 vrhova] “, Opatija, 3. 5. 1983., spis 32/83-T [polovica stranice].

4. HPS KP = Arhiva Komisije za priznanja Hrvatskoga planinarskog saveza Zagreb.

a. Rubeša, Zoran. 2000a. „Upitnik za člana planinarskog društva predloženog za dodjelu priznanja: Cerin, Mirna“.

b. Rubeša, Zoran. 2000b. „Upitnik za člana planinarskog društva predloženog za dodjelu priznanja: Cvek Tumpić, Jadranka“.

c. Rubeša, Zoran. 2000c. „Upitnik za člana planinarskog društva predloženog za dodjelu priznanja: Miletić, Cvjetana“.

d. Rubeša, Zoran. 2000d. „Upitnik za člana planinarskog društva predloženog za dodjelu priznanja: Rubeša, Ivica“.

e. Rubeša, Zoran. 2000e. „Upitnik za člana planinarskog društva predloženog za dodjelu priznanja: Rubeša, Mario“.

f. Rubeša, Zoran. 2000f. „Upitnik za člana planinarskog društva predloženog za dodjelu priznanja: Rubeša, Zoran“.

g. Rubeša, Zoran. 2000g. „Upitnik za člana planinarskog društva predloženog za dodjelu priznanja: Rubeša, Željko“.

h. Rubeša, Zoran. 2000h. „Upitnik za člana planinarskog društva predloženog za dodjelu priznanja: Stanta, Baldo“.

28 Greškom je upisano 50 umjesto 90 pod broj spisa (drugi broj odnosi se na godinu, a prvi na broj spisa u godini). 
i. Rubeša, Zoran. 2000i. „Upitnik za člana planinarskog društva predloženog za dodjelu priznanja: Stanta, Marija“.

j. Rubeša, Zoran. 2000j. „Upitnik za člana planinarskog društva predloženog za dodjelu priznanja: Stipanić, Darija“.

k. Rubeša, Zoran. 2000k. „Upitnik za člana planinarskog društva predloženog za dodjelu priznanja: Ujčić, Sandra“.

5. ZR = Arhiva Zorana Rubeše, Opatija.

a. Općinsko natjecanje 1985. = Općinsko natjecanje u pružanju prve pomoći 1985. godine; osvojeno II. mjesto [4 stranice: naslovnica, razvijene fotografije i prijavnica].

b. Općinsko natjecanje 1986. = Općinsko natjecanje u pružanju prve pomoći 1986. godine; osvojeno II. mjesto [2 stranice: naslovnica i prijavnica].

c. Općinsko natjecanje 1987. = Općinsko natjecanje u pružanju prve pomoći 1987. godine; osvojeno III. mjesto [8 stranica: naslovnica, razvijene fotografije, pitanja i prijavnica].

d. Općinsko natjecanje 1988. = Općinsko natjecanje u pružanju prve pomoći 1988. godine; osvojeno III. mjesto [7 stranica: naslovnica, razvijene fotografije i prijavnica].

6. $\mathrm{RT}=$ Arhiva Radovana Trinajstića, Ika.

a. Inicijativni odbor P.A. „Orljak“. 1984. „Poziv [Radovanu Trinajstiću]“, Opatija, 20. 2. 1984., spis 19/84 [1 stranica].

b. Inicijativni odbor. 1984. „Poziv [na osnivačku skupštinu P.D. 'Orljak']“, Opatija, 9. 3. 1984., spis 30/84 [1 stranica].

c. Planinarski dnevnik 23. 4. 1984.-16. 8. 1987. [192 str.].

7. $\mathrm{TCM}=$ Arhiva Tomislava i Cvjetane Miletić, Lovran.

a. Ferina, Slavko. 2000. [Dopis Komisije za zaštitu prirode Hrvatskog planinarskog saveza o imenovanja Marija Rubeše povjerenikom Komisije za Učku i Ćićariju, 1 list].

b. Ferina, Slavko. 2001. [Dopis Komisije za zaštitu prirode Hrvatskog planinarskog saveza o imenovanju Povjerenstva Komisije za zaštitu prirode Učke i Ćićarije, 1 list].

c. Rubeša, Mario, „Zamolba za podmirenje duga“ [upućena Gradu Opatiji], 26. 1. 2009. [kopija rukopisa].

\section{b) Novinski članci}

1. Blažević, Mirta. 1984. „Skup planinara u Opatiji“. Opatijska komuna, 6/70, 27. 12. 1984., str. 13. 
2. Blažević, Mirta. 1986. „Sjećanja dostojna poštovanja - uz akciju 'Žene na Lisini'“. Opatijska komuna, 8/85, 31. 3. 1986., str. 18.

3. Brajan, Darija. 1988. „Priznanja i pohvale“. Opatijska komuna, 10/108, 29. 2. 1988., str. 12.

4. Halilović, Abdurahman. 1984. „Marš 'Učka '84'“. Opatijska komuna, 6/62, 26. 4. 1984., str. 2.

5. I. S. 1999. „Učka, Papuk, Samorsko i Žumberačko gorje - novi parkovi prirode“. Hrvatski planinar, 91/6, str. 186.

6. Miletić, Cvjetana. 1981. „Zbor na Zadušćini“. Opatijska komuna, 3/28, 30. 6. 1981., str. 1.

7. Miletić, Cvjetana. 1986a. „Bogatiji za još jedno druženje“. Opatijska komuna, 8/83, 29. 1. 1986., str. 12.

8. Miletić, Cvjetana. 1986b. „Žene na Lisini“. Opatijska komuna, 8/84, 26. 2. 1986., str. 9.

9. Miletić, Cvjetana. 1986c. „Zastava na Orljaku“. Opatijska komuna, 8/86, 24. 4. 1986., str. 5.

10. Miletić, Cvjetana. 1986d. „Zastava na Orljaku“. Opatijska komuna, 8/87, 30. 5. 1986., str. 1-2.

11. Miletić, Cvjetana. 1986e. „Proslava na Lisini“. Opatijska komuna, 8/8990, 29. 7. 1986., str. 1.

12. Miletić, Cvjetana. 1988. „Start dobar, zadataka dovoljno - Sa skupštine Planinarskog društva 'Orljak'“. Opatijska komuna, 10/108, 29. 2. 1988., str. 12.

13. Miletić, Cvjetana. 1988b. „Proslava na Učki“. Opatijska komuna, 10/113, 26. 7. 1988., str. 1.

14. Miletić, Cvjetana. 1999a. „Planinarsko-turistička atrakcija Učke“. Hrvatski planinar, 91/3, str. 190.

15. Miletić, Cvjetana. 1999b. „Mladi u PD ‘Orljak’ u Opatiji“. Hrvatski planinar, 91/6, str. 96.

16. M. T. 1997. „Učka '96“. Hrvatski planinar, 89/1, str. 30.

17. Pažin, Dijana. 1986. „Priznanje 'Opatijskoj komuni'“. Opatijska komuna, 8/94, 25. 12. 1986., str. 13.

18. Rubeša, Marijan. 1985a. „Svečanost na Orljaku“. Opatijska komuna, 7/74, 24. 4. 1985., str. 8.

19. Rubeša, Marijan. 1985b. „Proleterska zastava na Orljaku“. Opatijska komuna, 7/75, 20. 5. 1985., str. 5.

20. Rubeša, Marijan. 1985c. „Stigli su planinari iz Bugojna“. Opatijska komuna, 7/75, 20. 5. 1985., str. 9.

21. Rubeša, Marijan. 1985d. „Orljak 711“. Opatijska komuna, 7/75, 20. 5. 1985., str. 9. 
22. Rubeša, Marijan. 1985e. „Planinari na natjecanju iz Prve pomoći“. Opatijska komuna, 7/76, 27. 6. 1985., str. 13.

23. Rubeša, Marijan. 1985f. „Planinari na natjecanju iz Prve pomoći“. Opatijska komuna, 7/75, 20. 5. 1985., str. 9.

24. Rubeša, Marijan. 1985g. „Crni vrh“. Opatijska komuna, 7/81, 26.11. 1985., str. 8.

25. Rubeša, Marijan. 1985h. „Metalni pečat na Crnom vrhu iznad Opatije“. Naše planine, 77/11-12, str. 205-206.

26. Rubeša, Marijan. 1985i. „III Memorijalni pohod planinara“. Opatijska komuna, 7/80, 30. 10. 1985., str. 10.

27. Rubeša, Marijan. 1985j. „Druženje planinara“. Opatijska komuna, 7/7778, 25. 7. 1985., str. 8.

28. Rubeša, Marijan. 1986a. „Izlet na Vodičku grižu“. Opatijska komuna, 8/83, 29. 1. 1986., str. 12.

29. Rubeša, Marijan. 1986b. „Omladinski marš na Učku“. Opatijska komuna, 8/86, 24. 4. 1986., str. 7.

30. Rubeša, Marijan. 1986c. „Na Titovom vrhu“. Opatijska komuna, 8/88, 26. 6. 1986., str. 7.

31. Rubeša, Marijan. 1986d. „Partizanskim stazama”. Opatijska komuna, 8/89-90, 29. 7. 1986., str. 12.

32. Rubeša, Marijan. 1986e. „Marš 'Stazama NOB-a'“. Opatijska komuna, 8/89-90, 29. 7. 1986., str. 9.

33. Rubeša, Marijan. 1986f. „Treći marš 'Partizanskim stazama'“. Opatijska komuna, 8/91, 26. 9. 1986., str. 2.

34. Rubeša, Marijan. 1986g. „Aktivnosti PD ‘Orljak’ ovog ljeta“. Opatijska komuna, 8/91, 26. 9. 1986., str. 9.

35. Rubeša, Marijan. 1986h. „Nova planinarska družina“. Opatijska komuna, 8/91, 26. 9. 1986., str. 10.

36. Rubeša, Marijan. 1986i. „Treći marš 'Partizanskim stazama'“. Naše planine, 78/9-10, str. 175.

37. Rubeša, Marijan. 1986j. „Ključ', nova planinarska družina u Opatiji“. Naše planine, 78/9-10, str. 175.

38. Rubeša, Marijan. 1987a. „Žene na Lisinu“. Opatijska komuna, 9/96, 28. 2. 1987., str. 11.

39. Rubeša, Marijan. 1987b. „Ugodno druženje“. Opatijska komuna, 9/98, 27. 4. 1987., str. 12.

40. Rubeša, Marijan. 1987c. „Vandalizam na Orljaku“. Opatijska komuna, 9/97, 27. 3. 1987., str. 9.

41. Rubeša, Marijan. 1987d. „Ponovno na Orljaku“. Opatijska komuna, 9/99, 29. 5. 1987., str. 10. 
42. Rubeša, Marijan. 1987e. „Uz proslavu Dana borca“. Opatijska komuna, 9/100, 29. 6. 1987., str. 10.

43. Rubeša, Marijan. 1987f. „Marš 'Partizanskim stazama'“. Opatijska komuna, 9/100, 29. 6. 1987., str. 12.

44. Rubeša, Marijan. 1987g. „Od Vedeža do Lisine“. Opatijska komuna, 9/103, 30. 9. 1987., str. 9.

45. Rubeša, Marijan. 1987h. „Na Zagradskom vrhu“. Opatijska komuna, 9/104, 28. 10. 1987., str. 12.

46. Rubeša, Marijan. 1987i. „Sretno - kam greste?“. Opatijska komuna, 9/105, 26. 11. 1987., str. 14.

47. Rubeša, Marijan. 1987j. „Planinari na Slavniku“. Opatijska komuna, 9/106, 25. 12. 1987., str. 12.

48. Rubeša, Marijan. 1988a. „Pod gojzericama škripi snijeg“. Opatijska komuna, 10/107, 26. 1. 1988., str. 8.

49. Rubeša, Marijan. 1988b. „Žene na Lisini“. Opatijska komuna, 10/108, 29. 2. 1988., str. 12.

50. Rubeša, Marijan. 1988c. „Pohod na Lisinu“. Opatijska komuna, 10/109, 29. 3. 1988., str. 15.

51. Rubeša, Marijan. 1988d. „Još jedan uspješan marš““. Opatijska komuna, 10/110, 26. 4. 1988., str. 2.

52. Rubeša, Marijan. 1988e. „'Čovjek i planina'“. Opatijska komuna, 10/110, 26. 4. 1988., str. 14.

53. Rubeša, Marijan. 1988f. „Prvomajski bivak“. Opatijska komuna, 10/111, 30. 5. 1988., str. 5.

54. Rubeša, Marijan. 1988g. ,Jubilarni marš“. Opatijska komuna, 10/114-115, 29. 9. 1988., str. 8.

55. Sakoman, Josip. 1985. „PD ‘Orljak’ iz Opatije“. Naše planine, 77/7-8, str. 142.

56. Stanta, Baldo. 1981. „Planinari aktiva 'Orljak' u akciji“. Opatijska komuna, 3/28, 30. 6. 1981., str. 9.

57. Stanta, Baldo. 1982. „Iz aktivnosti planinarskog društva 'Opatija'“. Opatijska komuna, 4/39, 27. 5. 1982., str. 18.

58. Stanta, Baldo. 1983. „Planinari aktiva 'Orljak'“. Opatijska komuna, 5/51, 31. 5. 1983., str. 9.

59. Stanta, Baldo. 1984a. „Veseli zimski praznici na Učki“. Opatijska komuna, 6/60, 29. 2. 1984., str. 10.

60. Stanta, Baldo. 1984b. „Učka '84': planinari 'Orljaka' - vodiči na maršu“. Opatijska komuna, 6/62, 26. 4. 1984., str. 8.

61. Starčević, Ante. 1995. „Učka '95'“. Hrvatski planinar, 87/9, str. 268. 
62. Starčević, Ante. 1996. „Nakon sječe na Sisolu“. Hrvatski planinar, 88/3, str. 94.

63. Trinajstić, Radovan. 1984a. „Zimovanje opatijskih planinara“. Opatijska komuna, 6/60, Opatija, 29. 2. 1984., str. 10.

64. Trinajstić, Radovan. 1984b. „Osnovano PD ‘Orljak’ u Opatiji“. Naše planine, 76/3-4, str. 94-95.

65. Trinajstić, Radovan. 1984c. „Osnovano planinarsko društvo 'Orljak'“. Opatijska komuna, 6/62, 26. 4. 1984., str. 9.

66. Trinajstić, Radovan. 1984d. „PD ‘Orljak’ u Opatiji“. Naše planine, 76/7-8, str. 157.

67. Trinajstić, Radovan. 1984e. „Crveni barjak na Orljaku“. Opatijska komuna, 6/63, 31. 5. 1984., str. 7.

68. Trinajstić, Radovan. 1984f. „Crveni barjak na Orljaku“. Opatijska komuna, 6/63, 31. 5. 1984., str. 12.

69. Trinajstić, Radovan. 1984g. „PD ‘Orljak’ iz Opatije“. Naše planine, 76/910, str. 190.

70. Trinajstić, Radovan. $1984 \mathrm{~h}$. „Partizanskim i planinarskim stazama“. Opatijska komuna, 6/67, 27. 9. 1984., str. 8.

71. Trinajstić, Radovan. 1984i. „Planinari u spomen Pazinskih odluka“. Opatijska komuna, 6/67, 27. 9. 1984., str. 7.

72. Trinajstić, Radovan. 1984j. „Planinarski aktiv 'Orljak’ u Opatiji“. Naše planine, 76/3-4, str. 95.

73. Trinajstić, Radovan. 1984k. „Opatijski planinari na Sljemenu“. Opatijska komuna, 6/69, 23. 11. 1984., str. 15.

74. Trinajstić, Radovan. 1985a. „Izlet planinara“. Opatijska komuna, 7/71, 29. 1. 1985., str. 12.

75. Trinajstić, Radovan. 1985b. „Planinari na Matić Poljani“. Opatijska komuna, 7/73, 26. 3. 1985., str. 2.

76. Trinajstić, Radovan. 1985c. „Skupština planinarskog društva 'Orljak'“. Opatijska komuna, 7/74, 24. 4. 1985., str. 8.

77. Trinajstić, Radovan. 1985d. „Članovi PD ‘Orljak’ uspješni vodiči“. Naše planine, 77/5-6, str. 110-111.

78. Trinajstić, Radovan. 1985e. „Planinari ‘Orljaka' uspješni vodiči“. Opatijska komuna, 7/74, 24. 4. 1985., str. 9.

79. Trinajstić, Radovan. 1985f. „100. obljetnica planinarstva“. Opatijska komuna, 7/74, 24. 4. 1985., str. 10.

80. Trinajstić, Radovan. 1985g. „100. obljetnica planinarstva na opatijskoj rivijeri“. Naše planine, 77/5-6, str. 111.

81. Trinajstić, Radovan. 1985h. „Skupština PD ‘Orljak’ u Opatiji“. Naše planine, $77 / 5-6$, str. 111. 
82. Trinajstić, Radovan. 1985i. „Opatijski planinari na Snježniku“. Opatijska komuna, 7/76, 27. 6. 1985., str. 13.

83. Trinajstić, Radovan. 1985j. „Metalni pečat na Orljaku (711m)“. Naše planine, 77/7-8, str. 142.

84. Trinajstić, Radovan. 1985k. „PD ‘Orljak’ iz Opatije“. Naše planine, 77/78, str. 142.

85. Trinajstić, Radovan. 19851. „Prvomajska svečanost na vrhu Orljaka“. Naše planine, 77/9-10, str. 176.

86. Trinajstić, Radovan. 1986a. „Planinari u Mrkoplju“. Opatijska komuna, 8/85, 31. 3. 1986., str. 14.

87. Trinajstić, Radovan. 1986b. „Skupština PD ‘Orljak’ Opatija“. Opatijska komuna, 8/88, 26. 6. 1986., str. 6.

88. Trinajstić, Radovan. 1986c. „Skupština PD ‘Orljak’ Opatija“. Naše planine, 78/9-10, str. 175.

89. Trinajstić, Radovan. 1988. „U obilasku spomen-obilježja“. Opatijska komuna, 10/111, 30. 5. 1988., str. 2.

90. Tumpić, Ivana. 1987. „Vikend u Istri“. Opatijska komuna, 9/96, 28. 2. 1987., str. 11.

91. Tumpić, Jadranka. 1986a. „Krijes uoči praznika“. Opatijska komuna, 8/87, 30. 5. 1986., str. 9.

92. Tumpić, Jadranka. 1986b. „Obnovljena markacija do Orljaka“. Opatijska komuna, 8/92, 30. 10. 1986., str. 13.

93. Tumpić, Jadranka. 1987a. „Zimovanje planinara“. Opatijska komuna, 9/95, 31. 1. 1987., str. 10.

94. Tumpić, Jadranka. 1987b. „Na Lisini“. Opatijska komuna, 9/98, 27. 4. 1987., str. 12.

95. Tumpić, Jadranka. 1987c. „Stazama NOB-a“. Opatijska komuna, 9/101102, 30. 7. 1987., str. 2.

96. Tumpić, Jadranka. 1987d. „Trodnevno druženje“. Opatijska komuna, 9/103, 30. 9. 1987., str. 8.

97. Tumpić, Jadranka. 1988a. „Pohod na Matić poljanu“. Opatijska komuna, 10/108, 29. 2. 1988., str. 2.

98. Tumpić, Jadranka. 1988b. „Na legendarnoj poljani“. Opatijska komuna, 10/109, 29. 3. 1988., str. 13.

99. Tumpić, Jadranka. 1988c. „Posjet Borovnici“. Opatijska komuna, 10/114115, 29. 9. 1988., str. 8.

100. Tumpić, Jadranka. 1988d. „Pohod na Triglav“. Opatijska komuna, 10/114115, 29. 9. 1988., str. 8.

101. Uredništvo. 1989. „Istarska društva“. Naše planine, 81/5-6, str. 141. 


\section{Intervjui}

1. Cvjetana Miletić (6. 11. 1943.-), intervju vođen 13. 9. 2021. u Lovranu.

2. Boris Petrić (9. 3. 1955.-), intervju vođen 19. 5. 2016. u Opatiji.

3. Zoran Rubeša (23. 10. 1967.-), intervju vođen 21. 7. 2016. u Opatiji.

4. Radovan Trinajstić (31. 5. 1950.-), intervju vođen 21. 9. 2021. u Iki.

\section{Literatura}

1. Eterović, Ivana; Tina Ružić. 2021. Prvih sedamdeset godina Planinarskoga društva „Opatija “. Opatija: Planinarsko društvo „Opatija“ Opatija.

2. Poljak, Željko. 1975. Hrvatske planinarske organizacije od 1874. do 1974. godine. Naše planine, 67/3-4, str. 233-256.

3. Simičević, Vedrana. 1997. „Planinarenje - sport i način života: planinarski klubovi u Opatiji“. Opatija - list Grada Opatije, 2/15, str. 24.

4. Slaviček, Ivo. 1984. „Planinari i žigolovci“. Naše planine, 76/3-4, str. 89-90.

5. Skorić, Marjan. 1999a. „Zeleno-plava opcija - što je to?“. Opatija - list Grada Opatije, 4/30-31, str. 30.

6. Skorić, Marjan. 1999b. „Šetališta u opatijskoj lječilišno-turističkoj ponudi“. Opatija - list Grada Opatije, 4/30-31, str. 33. 


\section{Summary}

\section{A CONTRIBUTION TO THE UNDERSTANDING OF THE HISTORY OF MOUNTAINEERING IN LIBURNIA: HISTORICAL OVERVIEW OF ACTIVITIES OF THE "ORLJAK" MOUNTAINEERING CLUB (1984-2010)}

Activities of the "Orljak" Mountaineering Club from Opatija (hereinafter: the Club) are underrepresented in the history of Croatian mountaineering. However, a quarter of a century of existence and notable activities in Liburnia justify the need to document such an important episode in local, regional, and even national mountaineering history. This paper, therefore, explores work and activities of the Club from its earliest days in the form of "Orljak" Mountaineering Section within "Opatija” Mountaineering Club (as of 1980), the establishment of independent Club (1984), the period of growth and intensive activities in the 1980s, gradual fading out in the 1990s up to final notable activities in the first decade of the 21 st century. The paper is based upon a thorough analysis of unpublished archival resources from several funds. This data is supplemented by interviews with people who were active members of the Club during a certain period, and with secondary literature. This data is little known, even within mountaineers' circles; therefore, the objectives of this research are to save from oblivion the work and activities of a mountaineering club and to adequately valorise its work as a lasting heritage of local, regional, and national (mountaineering) history.

Keywords: mountaineering, environmental protection, Liburnia, Opatija, "Orljak" Mountaineering Club 
Prilog 1. Predsjednici i tajnik Društva 1984.-2009.

\begin{tabular}{|l|c|}
\hline \multicolumn{2}{|c|}{ PREDSJEDNICI } \\
\hline Lucijan Slavić & $1984 .-1986$. \\
\hline Željko Rubeša & $1986 .-1995$. \\
\hline Zoran Rubeša & $1995 .-2009$. \\
\hline \multicolumn{2}{|c|}{ TAJNICI } \\
\hline Marijan Rubeša & $1984 .-2009$. \\
\hline
\end{tabular}

Prilog 2. Kretanje broja članova Društva 1984.-2009.

\begin{tabular}{|l|l|}
\hline GODINA & BROJ ČLANOVA (MLADI) \\
\hline 1985. & 135 \\
\hline 1986. & 150 \\
\hline 1988. & cca 100 (oko 60) \\
\hline 1995. & $58($ oko 30$)$ \\
\hline 1996. & $127(92)$ \\
\hline 1997. & $112(66)$ \\
\hline 2009. & $180(19)$ \\
\hline
\end{tabular}

